\title{
Factors Effecting Adenoma Detection During Screening Colonoscopy
}

\author{
Majid Abdulrahman Al-Madi, MBBS, FRCPC \\ Department of Epidemiology, Biostatistics and Occupational Health \\ McGill University, Montreal \\ Submitted: April/2011
}
"A thesis submitted to McGill University in partial fulfillment of the requirements of the degree of a Masters of Science in clinical epidemiology"

(C) Majid Abdulrahman Al-Madi, MBBS, FRCPC, 2011 


\section{ACKNOWLEDGMENTS}

I would like to present my thanks and appreciation to Dr. Maida Sewitch for the unlimited support and enthusiasm that she has provided throughout this project as well as her guidance in the many areas of epidemiological research.

A role model in the science and art of medicine, a mentor, and a friend are a few of the descriptions that I could express to Dr. Alan Barkun, a person that has introduced me to the field of research and had inspired me to pursue my post graduate training in epidemiology and science in general. The altruism and professionalism that Dr. Laurence Joseph has demonstrated throughout the period that I had known him has been an inspiration, it has been an honor and pleasure to work with him. In addition I extend my appreciation to Myriam Martel for her assistance and support in all phases of this study. I would like to thank all of Daphnée Beaulieu, Lilly Lang, and Stacy Dikareva for the help they had provided in the data extraction and without their assistance this study could not have been completed.

To my parents, Abdulrahman Al-Madi and Refa Malla, whatever I have achieved and will achieve throughout my career has been only through their unconditional love and wisdom.

My wife, Nouf Alwehaibi, has the greatest appreciation and love, her patience, support, faith have been the driving forces that have sustained my productivity and sanity.

My children Abdulrahman and Abdullah have been the source of my joy, and the repository of my dreams.

Majid 


\section{ABSTRACT}

Background. Adenoma detection rate (ADR) has been associated with the incidence of interval colorectal cancer (CRC) in patients undergoing screening colonoscopy.

Objective. This study aimed to identify factors that effect adenoma detection during screening colonoscopy.

Methods. A retrospective cross sectional study was conducted of patients who underwent screening colonoscopy between June $1^{\text {st }}$ and August $25^{\text {th }}$ 2009 at the McGill University Health Center. Variables were abstracted from two electronic databases: Endoworks (for colonoscopy reports) and OACIS (for pathology reports for polyps removed). Multivariable logistic regression analysis was performed using the software $\mathrm{R}$ to determine the association between patient, colonoscopy, endoscopist related variables, and adenoma detection.

Results. 430 sequentially performed colonoscopies met eligibility criteria and were included. In univariable analysis, higher likelihood of detecting adenomas was associated with male patients, increasing patient age, prior polyp removal, photo-documentation of the cecum, and increasing number of polyps detected; a lower likelihood of detecting adenomas was associated with average risk for CRC, colonoscopy performed by surgeon, increasing number of endoscopies and colonoscopies before the index colonoscopy, and increasing duration of time in the endoscopy unit. In multivariable analysis, increased likelihood of adenoma detection was 
associated with increasing patient age (in years) OR $1.04(95 \% \mathrm{Cl}, 1.02$ to 1.07), the more polyps detected the higher the odds of detecting an adenoma (OR $3.71(95 \% \mathrm{Cl}, 2.70$ to 5.10$)$, while lower likelihood for detecting adenoma was increased time (in hours) from the beginning of the endoscopy session till the index colonoscopy (OR $0.51(95 \% \mathrm{Cl}, 0.31$ to 0.79$)$.

Conclusions. In addition to patient characteristics, operator fatigue, as evidenced by a decrease in adenoma detection as time progresses from the start of the endoscopy session, is an important factor that should be considered in endoscopy scheduling. Further research is required to evaluate factors that would optimize the adenoma detection and performance of colonoscopy as a screening tool for CRC. 


\section{RÉSUMÉ}

Contexte. Le taux de détection d'adénome (TDA) a été associé avec l'incidence intervalle subséquente du cancer colorectal (CRC) chez les patients subissant une coloscopie de dépistage.

Objectif. Cette étude visait à identifier les facteurs affectant la détection d'adénome au cours d'une coloscopie de dépistage.

Méthodes Une étude rétrospective transversale a été menée chez les patients ayant subi une coloscopie de dépistage entre le 1er Juin et 25 août 2009 au Centre universitaire de Santé McGill. Les variables ont été extraites à partir de deux bases de données électroniques Endoworks (pour les rapports de coloscopie) et OACIS (rapports de pathologie pour les polypes enlevés). Une analyse multivariable de régression logistique a été effectuée en utilisant le logiciel $\mathrm{R}$.

Résultats. 430 coloscopies effectuées successivement rencontrèrent les critères d'admissibilité et ont été incluses. En analyse univariable, une probabilité de détection d' adénomes accrue a été notée chez les patients de sexe masculin, plus àgés, ayant eu une ablation de polypes antécédente, s'il y avait eu photo-documentation du caecum, et avec la présence d'un nombre de polypes plus élevés. La probabilité de détecter un adénome était affaiblie chez les patients à risque moyen de CCR, si la coloscopie était effectuée par un chirurgien, et avec un nombre croissant d'endoscopies et coloscopies complétées avant la coloscopie le même jour, ainsi qu'en augmentant la durée de temps passé ce jour-là dans 
l'unité d'endoscopie. En analyse multivariable, une augmentation de la probabilité de détection d'adénome a été associée avec l' augentation de l'âge du patient (en années) (OR=1,04 (IC 95\% (1,02 à 1,07)), un nombre accru de polypes détectés $(\mathrm{OR}=3,71$ ( $95 \% \mathrm{IC}, 2,70$ à 5,10$)$, tandis qu'une plus faible probabilité de détection d'adénome était associée avec une augmentation du temps (en heures) passé depuis le début de la session endoscopie jusqu'à la coloscopie de dépistage donnée (OR 0,51 (IC 95\%: 0,31 à 0,79).

Conclusions. En plus des caractéristiques de patients reconnus, la fatigue de l'endoscopiste, telle que reflétée par le temps écoulé depuis le début de la session d'endoscopie est associée avec une diminution significative du taux de détection d' adénomes. Ce facteur important doit donc être pris en compte dans la planification de la liste d'endoscopie dans un contexte de dépistage. D'autres recherches sont nécessaires pour évaluer les facteurs qui permettent d'optimiser la détection des adénomes et la performance de la coloscopie comme outil de dépistage pour le CCR. 


$\begin{array}{ll}\text { ABBREVIATIONS } \\ \text { ADR } & \text { Adenoma detection rate } \\ \text { CI } & \text { Confidence interval } \\ \text { CRC } & \text { Colorectal cancer } \\ \text { CT } & \text { Computerized tomography } \\ \text { CTC } & \text { Computed tomographic colonography } \\ \text { GI } & \text { Gastroenterologist } \\ \text { FIT } & \text { Fecal immunochemical test } \\ \text { FAP } & \text { Familial adenomatous polyposis } \\ \text { FICE } & \text { Fujinon intelligent chromoendoscopy } \\ \text { FIT } & \text { Fecal immunochemical test } \\ \text { HR } & \text { Hazard ratio } \\ \text { HNPCC } & \text { Hereditary non-polyposis colorectal cancer } \\ \text { MGH } & \text { Montreal General Hospital } \\ \text { MUHC } & \text { McGill University Health Center } \\ \text { NA } & \text { Not applicable } \\ \text { OR } & \text { Odds ratio }\end{array}$




\section{LIST OF TABLES AND FIGURES}

\section{TABLES}

Table 2.1 Screening exams for colorectal cancer.......................23

Table 2.2 Colonoscopy image-enhancing techniques.....................25

Table 2.3 Quality indicators endorsed by the Quality Assurance Task

Group of the National Colorectal Cancer Roundtable....................28

Table 2.4 Factors affecting the adenoma detection rate..................29

Table 2.5 The "Boston Bowel Preparation Scale" scoring system used for the description of the quality of the bowel preparation during colonoscopy

Table 2.6 the sensitivity of colonoscopy decreases as the size of the polyps decrease.

Table 3.1 Variables of interest............................................

Table 4.1 Patient and colonoscopy characteristics ......................43

Table 4.2 Description of colonoscopies per physician.....................44

Table 4.3 Characteristics and findings of screening colonoscopies based

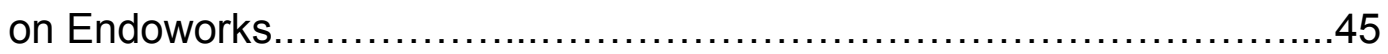

Table 4.4. The reasons for an incomplete colonoscopy and the level

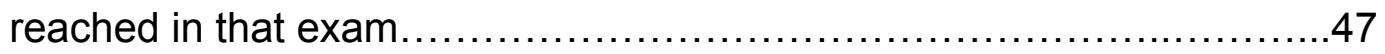

Table 4.5. Variables with regard to adenoma detection and the percentage of adenomas detected. .48

Table 4.6 Results of univarable and multivariable modeling for detection of an adenoma on screening colonoscopy. .57 
Table 4.7 Results of univariable and multivariable modeling for detection of an adenoma on screening colonoscopy when the analysis was restricted to average risk patients........................................5 


\section{FIGURES}

Figure $1.1 \mathrm{~A}$ broad based polyp ........................................

Figure $1.2 \mathrm{~A}$ colonoscopy demonstrating a large polyp....................16

Figure 1.3 CRC develops from polyps that contain adenomatous tissue

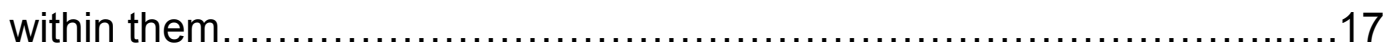

Figure 1.4 The aim of colorectal cancer screening is to intervene in the

natural progression of adenoma to colorectal cancer.......................17

Figure 1.5 A colonoscopy demonstrating the polyp in figure 1.2 after

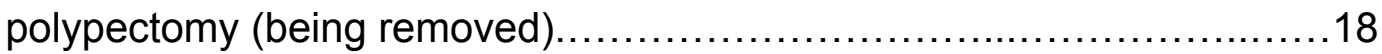

Figure 1.6 A colonoscopy demonstrating colorectal cancer.................18

Figure 2.1 The sequence of events prior and following the colonoscopy..23

Figure 4.1 The percentage of adenomas detected increases as the

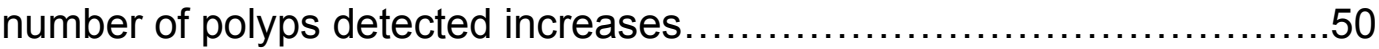

Figure 4.2 The percentage of adenomas detected decreases as the time (in hours) from the beginning of the endoscopy session increases.........50 Figure 4.3 Percentage of adenomas detected in relation to the sequence of index colonoscopy in relation to the number of colonoscopies..........51 Figure 4.4 Percentage of adenomas detected in relation to the sequence of index colonoscopy in relation to the number of endoscopies............51 Figure 4.5 Age distribution of the patients who underwent screening colonoscopy

Figure 4.6 Box plot of age of patients based on the gender of the endoscopist. 
Figure 4.7 Box plot of the number of polyps detected in relation to the

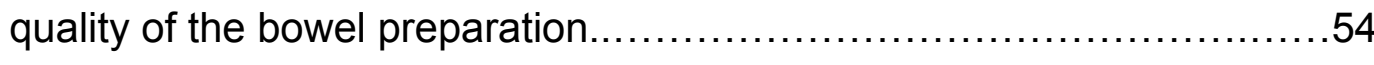
Figure 4.8 Box plot of the quality of the bowel preparation in relation to the time till the start of the index colonoscopy from the beginning of the

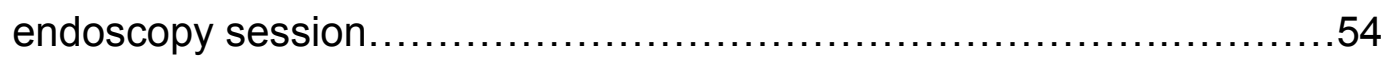

Figure 4.9 Pairs function in $\mathrm{R}$ to investigate confounding ..................55 


\section{TABLE OF CONTENTS}

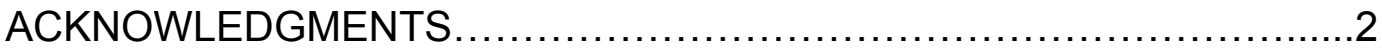

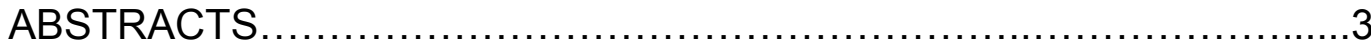

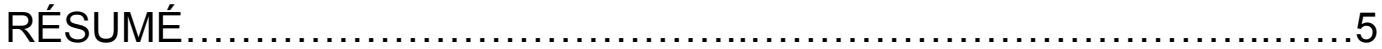

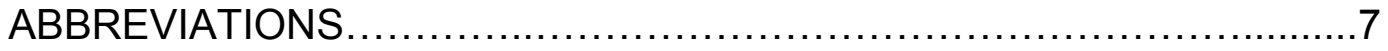

LIST OF TABLES AND FIGURES........................................

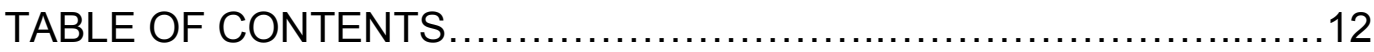

CHAPTER I: INTRODUCTION.............................................15

CHAPTER II: LITERATURE REVIEW...................................21

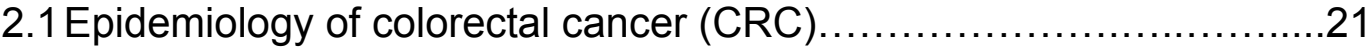

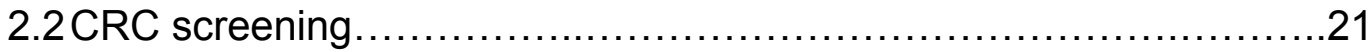

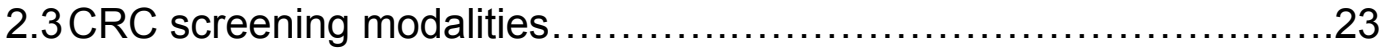

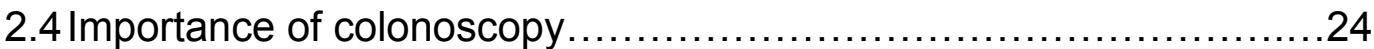

2.5Accuracy of colonoscopy in detecting CRC ...........................24

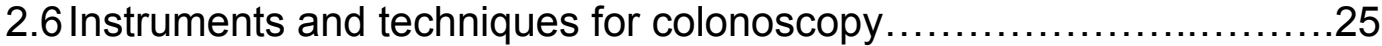

2.7 Impact of screening on the incidence CRC ..........................26

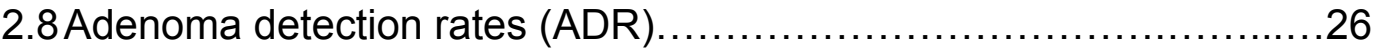

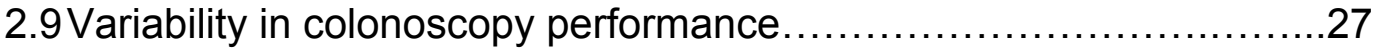

2.10 Quality indicators in screening colonoscopy .....................27

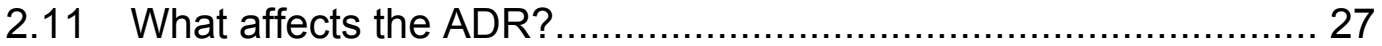

2.11.1 Patient factors .................................................

2.11.2 Level of sedation.......................................... 
2.11.3 Level of difficulty of the colonoscopy ......................30

2.11.4 Quality of the bowel preparation...........................30

2.11.5 Cecal intubation............................................

2.11.6 Photo-documentation of the cecum.........................32

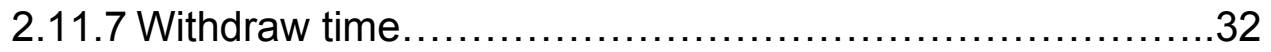

2.11.8 The size, shape, and position of the polyps.................32

2.11.9 Endoscopists performing screening colonoscopies...........33

2.11.10 The nurse assisting the endoscopist during the

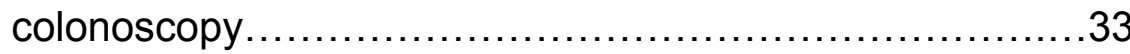

2.11.11 The timing and sequence of colonoscopies performed................................................... 33

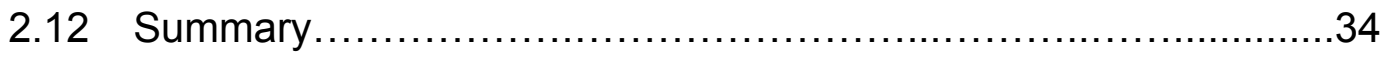

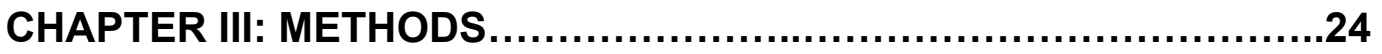

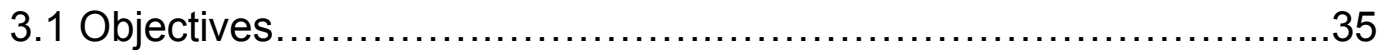

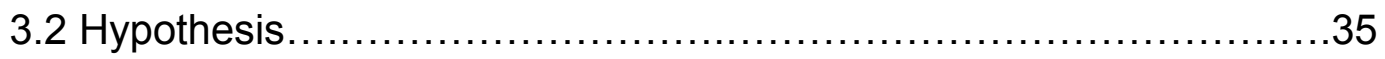

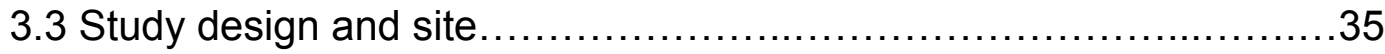

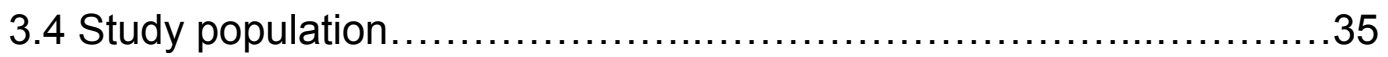

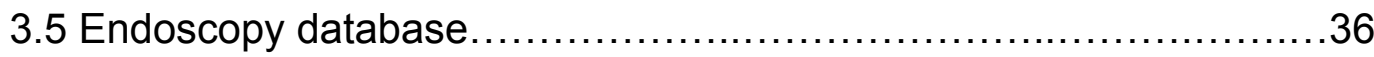

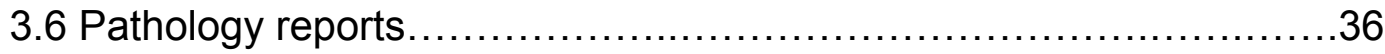

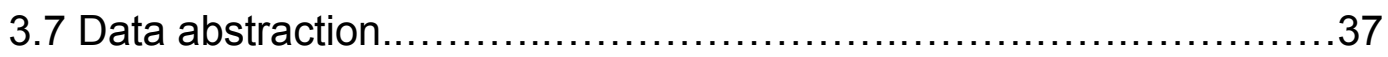

3.8 Data sources and variables of interest.............................

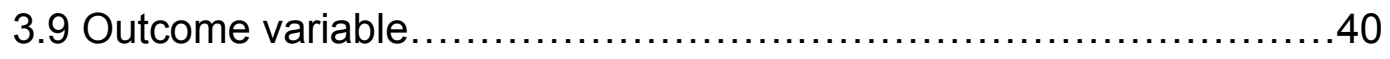

3.10 Sample size calculation.......................................... 41 
3.11 Institution approval............................................... 41

3.12 Method of data analysis............................................ 41

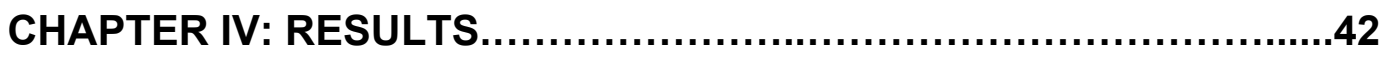

4.1 Descriptive statistics....................................................

4.2 Examining different descriptive graphs............................52

4.3 Univariable and multivariable model.................................55

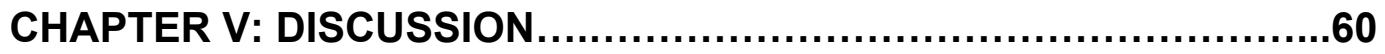

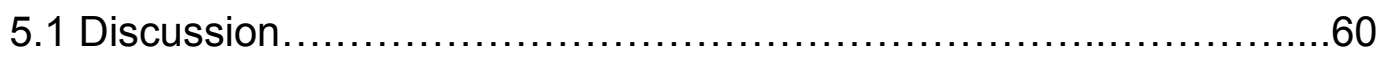

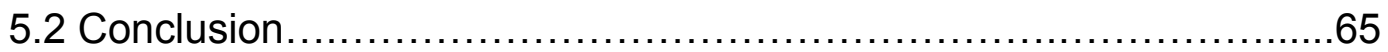

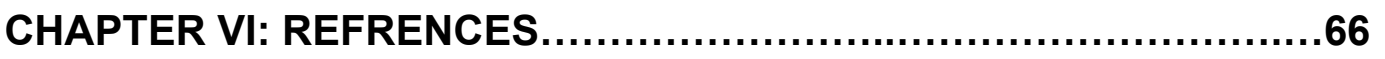

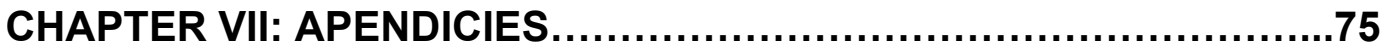




\section{CHAPTER I: INTRODUCTION}

Colorectal cancer $(\mathrm{CRC})$ is a malignant growth in the lining of the large intestine; it ranks third in cancer incidence and mortality for males and females alike with an estimated 142,000 new cases and more than 51,000 deaths in the United States in $2010^{1}$. CRC represents $10 \%$ of all incident cancers and 8 to $9 \%$ of all cancer related mortality ${ }^{1}$. Recent trends demonstrate declining incidence and mortality from $\mathrm{CRC}^{1,2}$ and screening, defined as "the identification of asymptomatic disease or risk factors" ${ }^{3}$, is thought to play a major role in these declines ${ }^{1,2}$.

CRC develops from colonic polyps (Figure 1.1 and 1.2), which are projections of tissue that develop on the lining of the colon; these polyps could harbor tissue, adenomas, which predisposes to CRC (Figure 1.3). The intent of CRC screening is to intervene in the natural progression of adenoma to carcinoma (Figure 1.4) by performing a polypectomy (removal of the polyp) (Figure 1.5). Polypectomy removes the tissue believed to be causal in the development of $\mathrm{CRC}^{4}$ (Figure 1.6), thereby decreasing the incidence of $\mathrm{CRC}^{5}$ and improving survival ${ }^{2,6-9}$

The preferred method of screening is colonoscopy (examining the colon with a colonoscope $)^{10}$ as it allows for the simultaneous examination of the colon and removal of any polyps that are detected. Colonoscopy requires a number of steps that will be discussed in the following chapter. 
Figure 1.1. A broad based polyp

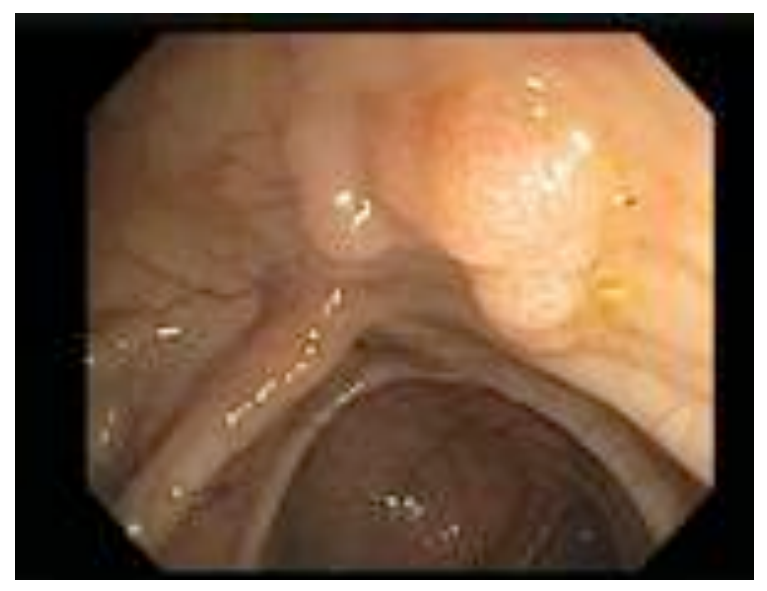

Figure 1.2. A colonoscopy demonstrating a large polyp

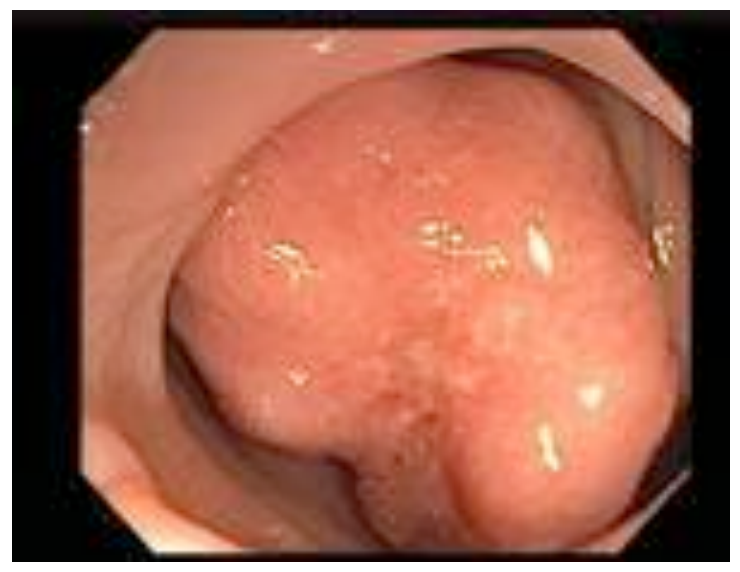


Figure 1.3 CRC develop from polyps that contain adenomatous tissue within them.

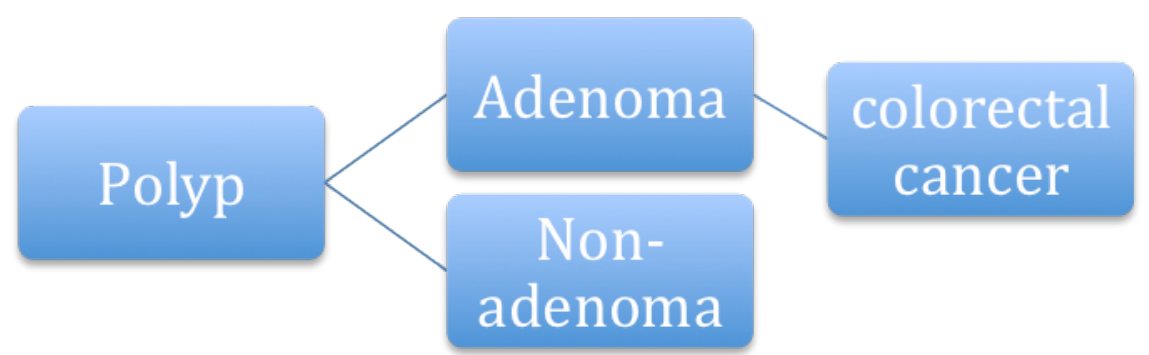

Figure 1.4 The aim of CRC screening is to intervene in the natural progression of adenoma to CRC. 
Figure 1.5. A colonoscopy demonstrating the polyp in figure 1.2 after polypectomy (being removed).

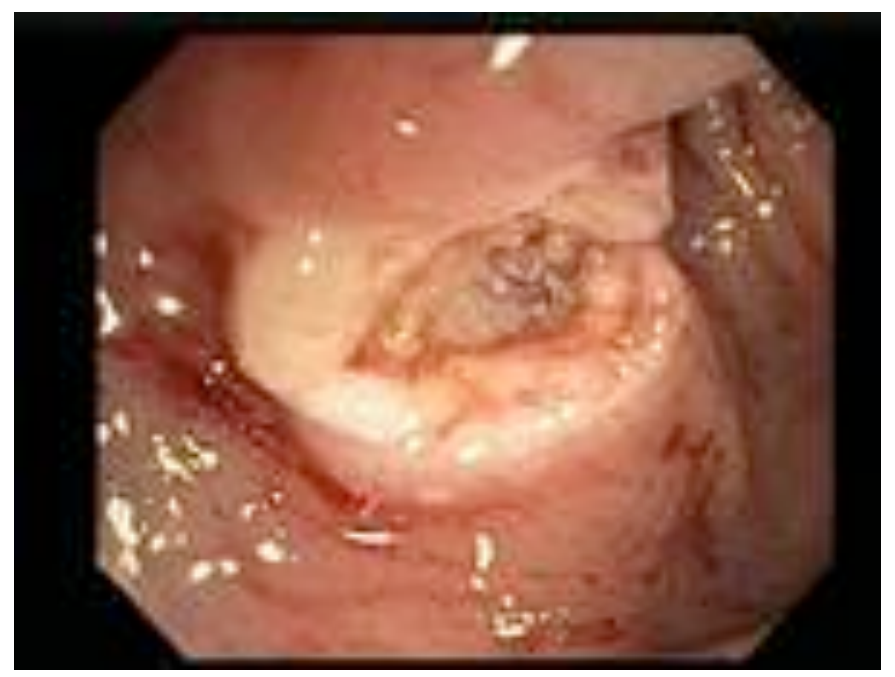

Figure 1.6 A colonoscopy demonstrating CRC.

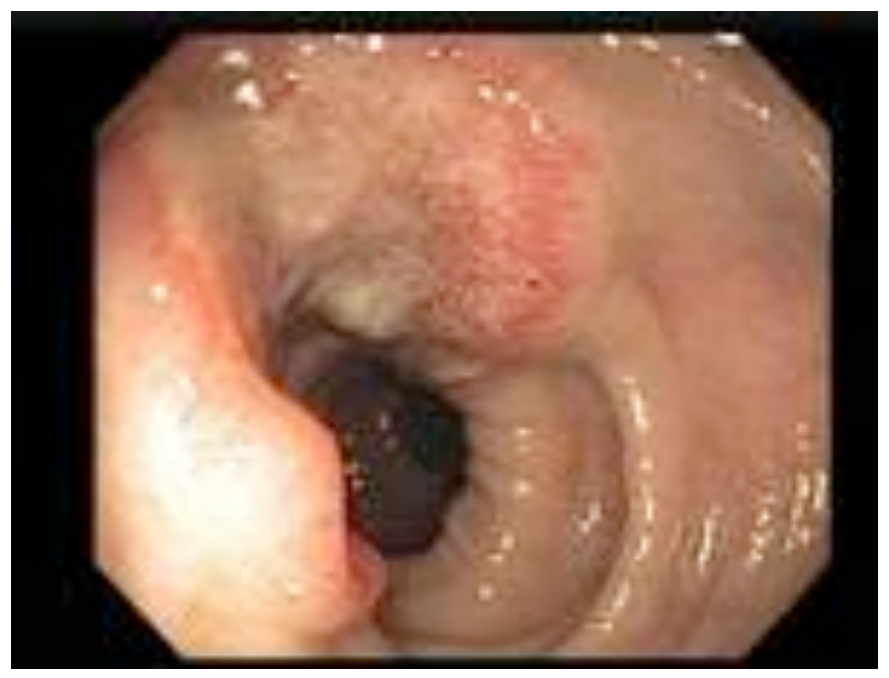


The launching of regional and provincial CRC screening programs in Canada has led to an increase in the number of annual colonoscopies. Although current CRC screening programs reach only one fifth of the eligible population ${ }^{11}$, numbers will increase because of efforts to boost CRC screening rates. Colonoscopy-related quality measures (i.e. withdrawal time, cecal intubation rate, polyp detection rate, adenoma detection rate (ADR) and polypectomy) have been put forth because of the need to establish standards.

The quality of a colonoscopy is a complex construct that incorporates the appropriateness of the reason for performing the colonoscopy, the diagnostic accuracy (the ability of the test to correctly classify the presence or absence of the target disorder ${ }^{12}$ ) and the safety of the colonoscopy. Over the last 10 years, endpoints in colonoscopy performance have been refined from conducting a full examination of the colon ${ }^{13-15}$ to more specific targets ${ }^{16}$ that have come to be known as quality indicators ${ }^{17-20}$. These quality indicators or benchmarks strive to achieve a common standard of practice across endoscopy centers with the main goal of maximizing the detection of adenomas during screening colonoscopy and the prevention of progression to CRC.

$\mathrm{CRC}$ is a relatively common disease that requires allocation of significant resources to provide $\mathrm{CRC}$ screening programs. Improving the performance of colonoscopy is a major concern. Thus, we sought to identify factors that effect adenoma detection during screening colonoscopy. Identifying factors that either augment or dampen adenoma detection could be targeted in the future with the aim of increasing the effectiveness of colonoscopy as a screening instrument. 
The overall study objective is to identify factors that are associated with adenoma detection.

Specifically, we will examine the relationships between the adenoma detection rate and factors that likely impact it, including: hours, endoscopies (gastroscopies and colonoscopies) and colonoscopies the endoscopist worked/performed prior to the index colonoscopy on the day of the procedure and adenoma detection.

In this thesis, we will first review the literature on the known factors that affect the ADR, and then present the study methodology and results. We used an endoscopy report database at the Montreal General Hospital (MGH), Montreal, Canada and included consecutive individuals who had undergone screening colonoscopies. We obtained variables related to patients including the patients age, sex, family history of CRC, previous colonoscopy, prior polyp removal, and CRC risk. Variables related to the colonoscopy were obtained as well as the pathology reports of the polyps removed. Finally we discuss and interpret the findings, and provide concluding remarks. 


\section{CHAPTER II: Literature review}

\subsection{Epidemiology of CRC}

$\mathrm{CRC}$ is the third leading cause of cancer deaths in North America ${ }^{1}$, with an estimated 142,000 new cases and 51,000 deaths in 2010 in the USA ${ }^{1}$, CRC constitutes $10 \%$ of all new cancers and $8 \%$ to $9 \%$ of cancer-related mortality ${ }^{1}$. The age standardized CRC incidence and death rates over the last two decades have been declining, ${ }^{2}{ }^{21}$ but the absolute number of CRC cases are increasing due to aging of the population ${ }^{22}$. At the time of screening colonoscopy, $1 \%$ of screenees are found to have invasive cancer $^{23}$, and $7.9 \%$ have advanced adenoma (an adenoma with an increased risk of transforming to $\mathrm{CRC})^{23}$.

\subsection{CRC screening}

Screening is defined as "the presumptive identification of unrecognized disease or defect by the application of tests, examinations or other procedures which can be applied rapidly"12. Another definition is "the identification of asymptomatic disease or risk factors"3.

For a screening test to be effective, it has to fulfill the following conditions:

1- Early detection of the disease being screened should improve prognosis.

2- The disease should be detectable at a preclinical stage.

3- The benefit that early treatment conveys should exceed the cost of screening ${ }^{24}$.

CRC screening fulfils these conditions, it is performed on asymptomatic individuals, has a lengthy preclinical stage (10 to 15 years) ${ }^{25}$ during which polyps can be detected and removed (polypectomy) thereby decreasing the incidence of $\mathrm{CRC}^{5}$ and improving survival ${ }^{6-9}$. Benefits of $\mathrm{CRC}$ screening have been demonstrated in several long-term cohort studies ${ }^{26-29}$ and, not surprisingly, professional and governmental organizations 
advocate for CRC screening; these include the American Cancer Society, the U.S. Multi-Society Task Force on Colorectal cancer, the American College of Radiology, the U.S. Preventive Services Task Force ${ }^{30,31}$, the American College of Gastroenterology ${ }^{10}$, the Canadian Association of Gastroenterology and the Canadian Digestive Health Foundation ${ }^{32}$, as well as the Canadian Task Force on Preventive Health Care $^{33}$.

CRC screening is recommended for individuals aged 50 to 75 years, who do not have complaints or manifest findings on physical examination or other investigations that could be attributed to CRC. CRC screening outside this age range should be on an individual basis and only up to the age of 85 years ${ }^{31}$; it can be performed prior to the age of 50 years in people who are at high risk for developing CRC as stated by U.S. Agency for Health Care Policy and Research ${ }^{34}$, such as patients with a family history of an inherited polyposis syndrome or inflammatory bowel disease ${ }^{34,35}$, although in the literature these cases are referred to as screening people at high risk for $\mathrm{CRC}$, these might be classified as surveillance colonoscopy as per prior guidelines that dated to $1997^{5}$. The U.S. Multi-Society Task Force on Colorectal Cancer $^{36}$ stated that colonoscopy may be performed for the purpose of screening in people with complaints such as abdominal pain and altered bowel habit (a change in the individuals bowel movements to diarrhea or constipation) with no evidence of bleeding depending on the patients age and family history. The sequence of events that precede and follow a colonoscopy are demonstrated in figure 2.1 
Figure 2.1 The sequence of events prior and following the colonoscopy
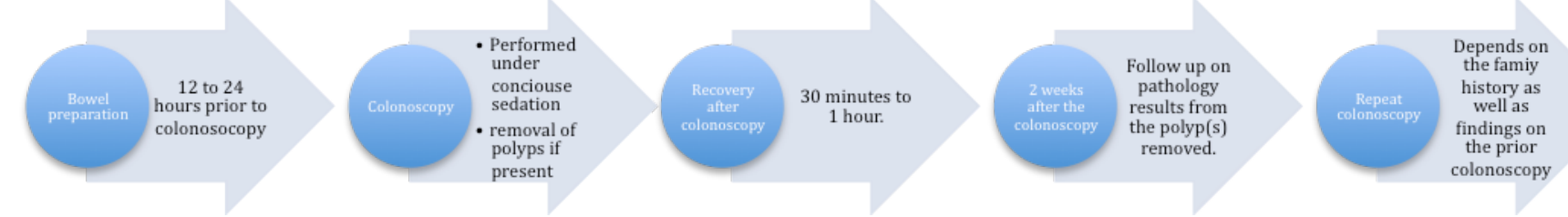

\subsection{CRC screening modalities}

Several modalities for CRC screening (Table 1 ) have been endorsed by the various soceties ${ }^{30-32,35}$ including: fecal testing, flexible sigmoidoscopy, colonoscopy, or computed tomographic colonography (CTC or virtual colonoscopy). These modalities can be divided into those that depend on fecal testing and those that structurally assess the colon.

Table 2.1 Screening exams for CRC

$\begin{array}{ll}\text { Fecal tests } & \text { Guaiac test, fecal occult blood test (FOBT) } \\ & \text { Fecal immunochemical test (FIT) } \\ & \text { Stool deoxyribonucleic acid (DNA) test } \\ \text { Structural tests } & \text { Double contrast barium enema } \\ & \text { Flexible sigmoidoscopy } \\ & \text { Colonoscopy } \\ & \text { Computed tomographic colonography (CTC) }\end{array}$




\subsection{Importance of colonoscopy}

Colonoscopy is the examination of the lining of the colon using a camera on a flexible tube that is inserted through the anus and advanced to the cecum (Figure 2.2). Colonoscopy is used to examine the colon and to remove polyps; its use as a screening tool for CRC has increased over the years $^{37}$ as it is the most accurate test compared to other screening tools . However, with a risk of 3.1 complications per 1000 colonoscopies performed $^{38}$, colonoscopy also has the highest risk of complications compared to other screening tools ${ }^{38}$. These complications are not nonsignificant and include perforation of the colon, bleeding and death as well as complications from the sedative medications used during the colonoscopy.

\subsection{Accuracy of colonoscopy in detecting CRC}

Accuracy is defined as "the ability of a diagnostic test to correctly classify the presence or absence of the target disorder"12 and is usually measured by the sensitivity and specificity of the test. Sensitivity is " the probability that a diseased person (case) in the population tested will be correctly identified as diseased by the test", while specificity is "the probability that a person without the disease (non-case) will be correctly identified as nondiseased by the test" ${ }^{\prime 2}$. Colonoscopy has a sensitivity of $85 \%$ to $95 \%{ }^{39-41}$ and a specificity of $99 \%$ to $100 \%{ }^{42-44}$.

Adenoma detection is the entire process of identifying and removing polyps during colonoscopy that are subsequently found to be adenomatous (a precursor for $\mathrm{CRC}$ ) on examination by a pathologist. It is believed that hyperplastic polyps have no potential to evolve into CRC. Variation in ADR between endoscopists has been of interest with recent studies suggesting that colonoscopy is protective for CRC on the left as opposed to right side of the colon ${ }^{9,44,45}$. Factors that affect adenoma detection include polyp size, where the sensitivity of colonoscopy 
decreased as the polyp size decreased with an overall miss rate of $20 \%$ to $24 \%{ }^{46,47}$ and a tendency to miss adenomas in the right colon compared to the left side, $27 \%$ and $21 \%$ respectively. This has also been reproduced in studies comparing CTC to colonoscopy and found that the miss rate of colonoscopy for polyps greater than $10 \mathrm{~mm}$ in size was from $2 \%$ to $12 \%{ }^{39}$, 40,48 . This miss rate is a compound of different factors that will be discussed.

The optimal polyp detection rate for colonoscopy is $44 \%{ }^{49}$ and the ADR, defined as the proportion of patients undergoing colonoscopy and found to have adenomas on histological examination, is $22 \%$ to $25 \%{ }^{50-52}$ based on large cohort studies.

\subsection{Instruments and techniques for colonoscopy}

Multiple technologies and techniques have been added to colonoscopy with the intent of improving the sensitivity of colonoscopy (Table 2.2). However, when compared to conventional colonoscopy ${ }^{53-63}$, they either had no impact on the ADR or had limitations that rendered them impractical; these included extra time spent performing these advanced colonoscopic techniques or the costs and specialized expertise needed.

Table 2.2 Colonoscopy image-enhancing techniques

\section{Colonoscopy image enhancing techniques}

Wide angle viewing scope

Fujinon intelligent chromoendoscopy (FICE) system

Chromoendoscopy

Narrow band imaging

Tissue spectroscopy

Magnifying colonoscopy

Third eye retroscope 


\subsection{Impact of screening on CRC incidence}

In 1993 The National Polyp Study ${ }^{26}$ found that colonoscopy reduced the incidence of CRC by up to $90 \%$. Although other studies demonstrated a reduction in the incidence of $\mathrm{CRC}$ with the use of colonoscopy ${ }^{28,64-66}$ none replicated the magnitude of the National polyp study ${ }^{67,68}$. Reasons for the discrepancies might be related to methodological issues as the investigators in the National polyp study had used historical control groups, where the intervention group (polypectomy) was conducted between 1980 and 1990 while the reference groups were from the mayo clinic (1965 to 1970), St. Mark's hospital (1957 to 1980), and the Surveillance, Epidemiology, and End Results (SEER) program (1983 to $1987)^{26}$. A decrease in mortality rates from CRC has been associated with the increase in the utilization of colonoscopy services ${ }^{69}$. On a population basis, one ecologic study found that every $1 \%$ increase in the rate of screening colonoscopy was associated with a $3 \%$ decrease in risk of death from $\mathrm{CRC}^{70}$.

Two Canadian studies from Ontario ${ }^{9}$ and Manitoba $^{71}$ demonstrated that although there was a reduced risk of dying of CRC in patients undergoing attempted colonoscopy, this reduction in death rate was from left- as opposed to right-sided CRC, which might be due to incomplete colonoscopies or poor bowel preparation quality on the right side compared to the left.

Evaluating the impact of colonoscopy on CRC incidence and mortality has been hampered by the lack of randomized controlled trials that compare colonoscopy to either other CRC screening modalities or no screening ${ }^{72}$.

\subsection{Adenoma detection rates (ADR)}

ADR is defined as the proportion of all patients undergoing colonoscopy who are found to have adenomas on histological examination and is the definition we used in this study. Advanced adenomas are defined as those that are $\geq 10 \mathrm{~mm}$ in size, or that are histologically described as villous or 
have high grade dysplasia ${ }^{73}$, these are all features that the adenoma is at high risk of becoming a cancer.

The ADR for the individual endoscopist was found to be inversely related incidence of interval CRC, that is the development of CRC in the period between the initial colonoscopy and the scheduled repeat colonoscopy ${ }^{74}$.

\subsection{Variability in colonoscopy performance}

Colonoscopy as a screening tool for detecting pre-cancerous and cancerous lesions is variable as evidenced by the incidence of CRC in patients who had undergone screening colonoscopies and were deemed free from polyps and were supposed to have a repeated screening colonoscopy at a latter date ${ }^{9,67,75}$. The factors leading to these "failures", or what has been called "interval CRC", are numerous and will be elaborated on.

A common issue in a number of these studies is that colonoscopy is used as its own reference standard; this has been challenged when colonoscopy is compared to $\mathrm{CTC}^{76}$.

\subsection{Quality indicators in screening colonoscopy}

With the aim of establishing a standardized system for colonoscopy performance, the Quality Assurance Task Group of the National Colorectal Cancer Roundtable ${ }^{77}$ set forth a number of benchmarks that have been collectively called "Quality Indicators" (Table 2.3). In the United States, some of these benchmarks, such as the ADR and cecal intubation rate, are being advocated as endpoints that should be reported for colonoscopy reimbursement purposes ${ }^{78}$.

\subsection{What affects the ADR?}

Several variables related to the colonoscopy are identified in the literature as impacting the ADR (Table 2.4) 
Table 2.3 Quality indicators endorsed by the Quality Assurance Task

Group of the National Colorectal Cancer Roundtable ${ }^{77}$

\begin{tabular}{|l}
\hline Colonoscopy report \\
\hline Patient demographics and history \\
\hline Assessment of patient risk and comorbidity \\
\hline Procedure indication(s) \\
Procedure technical description \\
\hline Colonoscopic finding \\
\hline Assessment \\
\hline Intervention/unplanned events \\
\hline Follow-up plan \\
\hline Pathology \\
\hline Benchmarks that are used in quality audits \\
\hline Bowel preparation quality: percent adequate to detect polyps > 5 mm \\
Cecal intubation rate \\
\hline Rate of photodocumentation of cecal landmarks \\
\hline Mean colonoscopic withdrawal time in patients without polypectomy or biopsy \\
\hline Adenoma detection rate in first time screening examination based on patients sex \\
Adverse or unplanned events occurring within 24 hours of colonoscopy \\
\hline Rates of: hospitalization, bleeding requiring transfusion, bleeding requiring \\
unplanned endoscopic intervention, perforation, and surgery. \\
Rate of documentation of recommendations for follow up \\
\hline
\end{tabular}


Table 2.4 Factors affecting the adenoma detection rate

Factors affecting the adenoma detection rate

\begin{tabular}{|c|c|}
\hline Patient & Age \\
\hline & Sex \\
\hline & Family history of CRC \\
\hline & Lifestyle (obesity and diet) \\
\hline & Socioeconomic status \\
\hline & Smoking \\
\hline & Dietary habits \\
\hline & Primary care physician \\
\hline Colonoscopy & Level of difficulty of the colonoscopy \\
\hline & Quality of the bowel preparation \\
\hline & Cecal intubation \\
\hline & Withdrawal time \\
\hline & Size and position of the polyp \\
\hline & Specialty of the endoscopist \\
\hline & Experience of the assisting nurse \\
\hline & Timing of the colonoscopy \\
\hline & Level of sedation \\
\hline Physician & Specialty \\
\hline & Age \\
\hline & Sex \\
\hline Nurse & Experience in assisting in the colonoscopy \\
\hline
\end{tabular}




\subsubsection{Patient factors}

Numerous risk factors are associated with an increased risk for developing adenomas. Increasing age and male gender ${ }^{51,79}$ are associated with increased risks for adenomas with males having double the rate compared to females ${ }^{80}$. Other risk factors include, family history of CRC (OR 1.62, $95 \% \mathrm{Cl}$ 1.16-2.26) (1) $^{81}$ increased abdominal visceral adipose tissue (central obesity) or increased body mass index ${ }^{79}, 82,83$, cigarette smoking ${ }^{83-85}$, dietary habits (amount of fiber intake, energy percentage from fat, red and processed meat, and fruits and vegetables) ${ }^{83}$.

\section{Colonoscopy factors}

\subsubsection{Level of sedation}

Colonoscopy in North America is performed under conscious sedation, defined as a level of sedation between being conscious and unconscious. Medications are administered intravenously prior to the start of the colonoscopy with the aim of decreasing discomfort; additional medication is administered intra-procedurally at the discretion of the endoscopist. The administration of conscious sedation is associated with an increased rate of cecal intubation and polyp detection ${ }^{86}$.

\subsubsection{Level of difficulty of the colonoscopy}

Each endoscopist subjectively assesses the level of difficulty in performing the colonoscopy. Assessments are confounded by other factors including adequacy of sedation and quality of the bowl preparation prior to colonoscopy.

\subsubsection{Quality of the bowel preparation}

The quality of the bowel preparation is gauged by the endoscopist's ability to visualize the lining of the colon. When the quality of the bowel preparation is poor, visualization of the colonic mucosa is impaired by the 
colonic contents. It has been demonstrated that the quality of the bowel preparation affects the $A D R^{87-89}$ although it seems to affect detection of smaller polyps ( $\leq 9 \mathrm{~mm}$ ) as opposed to larger ones (OR $1.2395 \% \mathrm{Cl}, 1.19$ $-1.28)^{88}$. Poor quality preparations are more often encountered in elderly and hospitalized patients ${ }^{89}$. The quality of the bowel preparation is commonly described by the endoscopist using a scoring system described in table $2.5^{90}$

Table 2.5 The "Boston Bowel Preparation Scale" scoring system used for the description of the quality of the bowel preparation during colonoscopy ${ }^{90}$.

\section{Score Description}

0 Unprepared colon segment with mucosa not seen due to solid stool that cannot be cleared.

1 Portion of mucosa of the colon segment seen, but other areas of the colon segment not well seen due to staining, residual stool and/or opaque liquid.

2 Minor amount of residual staining, small fragments of stool and/or opaque liquid, but mucosa of colon segment seen well.

3 Entire mucosa of colon segment seen well with no residual staining, small fragments of stool or opaque liquid

\subsubsection{Cecal intubation}

Cecal intubation is defined as passing the colonoscope beyond the iliocecal valve and visualizing the cecum. Reaching the cecum implies completion of the colonoscopy. A complete colonoscopy is achieved in $97 \%{ }^{23,91}$ of patients undergoing screening colonoscopy. 


\subsubsection{Photo-documentation of the cecum}

A photographic still image of the cecum provides good evidence that a complete examination of the colon was performed.

\subsubsection{Withdrawal time}

The withdrawal time is defined as the number of minutes it takes to withdraw the colonoscope from the cecum to the anal verge and calculated as the mean number of minutes per colonoscopy. Withdrawal

time has been studied extensively ${ }^{49,50,92-94}$,and found to be associated with the ADR with those taking on average more than 6 minutes detecting adenomas more than those with a mean time of less than 6 minutes $(28.3 \% \text { vs. } 11.8 \%)^{50}$.

Although withdrawal time was associated with an increased ADR, this was not associated with a decreased incidence of advanced neoplasia or cancer, in the following 5 years ${ }^{95}$.

\subsubsection{The size, shape, and position of the polyps}

A meta-analysis that had included studies where two colonoscopies were performed on the same individuals on the same day found that miss rate for polyps of any size was $22 \%$ (Table 2.6$)^{96}$.

A study utilizing a new enhancing visual accessory (third eye retroscope) increased the adenomas detected by $11 \%{ }^{97}$, this increase in adenoma detection is thought to be because of polyps and adenomas on the proximal side of colonic folds that are difficult to examine by conventional colonoscopy, this is supported by the finding of a $12 \%$ miss rate by colonoscopy for adenomas when compared to $\mathrm{CTC}^{76}$, the majority of these were on the proximal side of colonic folds. Flat polyps are more difficult to identify and at the same time might have a different biology ${ }^{98}$. 
Table 2.6 the sensitivity of colonoscopy decreases as the size of the polyps decrease

\begin{tabular}{|cc|}
\hline Size of adenoma & Miss rate OR $(95 \% \mathrm{Cl})$ \\
\hline Any size & $22 \%(19 \%$ to $26 \%)$ \\
\hline $1-5 \mathrm{~mm}$ & $26 \%(27 \%$ to $35 \%)$ \\
$5-10 \mathrm{~mm}$ & $13 \%(8 \%$ to $18 \%)$ \\
$\geq 1 \mathrm{~cm}$ & $2.1 \%(0.3 \%$ to $7.3 \%)$ \\
\hline
\end{tabular}

\section{Physician factors}

\subsubsection{Endoscopist characteristics}

Endoscopists vary widely in their $A D R^{80,99-102}$ and rates of complications from performing a lower endoscopy ${ }^{103,104}$. Variation might be related to age and sex of the endoscopist ${ }^{100}$. Specialty may also influence the ADR since the incidence of $\mathrm{CRC}$ following a negative colonoscopy was higher in colonoscopies performed by non-gastroenterologist compared to gastroenterologist ${ }^{105}$. The rate for subsequent CRC was higher when the index colonoscopy was performed by a surgeon (the hazard ratio (HR) 1.39, $(95 \% \mathrm{Cl}, 1.16 \text { to } 1.67)^{106}$.

\subsubsection{The nurse assisting the endoscopist during the colonoscopy} Number of years of experience for endoscopy nurses assisting with the colonoscopy effects the colonoscopy quality and even polyp detection rates but not $A D R^{52}$.

\subsubsection{The timing and sequence of colonoscopies performed}

There is a higher probability of incomplete colonoscopies OR 1.64 $(95 \% \mathrm{Cl}, 1.11$ to 2.44$)$ and inadequate bowl preparation in screening colonoscopies performed in the afternoon compared to those performed in the morning 108, 109. The ADR also has been found to be higher in colonoscopies performed in the morning OR $1.2(95 \% \mathrm{Cl}, 1.06-1.4)$ with a trend in decreasing ADR with each hour ${ }^{110}$, these finding were 
reproduced in a second study ${ }^{111}$. In a study where endoscopists performed endoscopies on a three shift per day pattern, the timing of the colonoscopy had no impact on the polyp detection rate ${ }^{112}$. These findings might imply that the timing of the endoscopy session does not have an effect on polyp detection but rather the length of the endoscopy session, and that endoscopists start to fatigue with increased time spent performing endoscopic procedures.

\subsection{Summary}

Although CRC carries significant morbidity and mortality and affects a large segment of the population, screening may prevent it. Colonoscopy has emerged as the preferred CRC screening modality given its diagnostic and therapeutic potential and impact on the incidence of CRC but it is associated with non-negligible risks for complications related to the bowel cleansing preparation, the colonoscopy itself and the medication administered during colonoscopy. Furthermore, many factors affect its diagnostic accuracy and in particular the ADR. For these reasons quality indicators have been proposed by gastrointestinal societies with the aim of achieving a common standard for the test performance of colonoscopy.

Thus, we aimed to evaluate the influence of different factors on adenoma detection during screening colonoscopy and to examine the relationship between the numbers of: hours, endoscopies (gastroscopies and colonoscopies) and colonoscopies the endoscopist worked/performed prior to the index colonoscopy and adenoma detection. 


\section{CHAPTER III: METHODS}

\subsection{Objectives}

The objectives of the present study were:

1) The overall study objective is to identify variables that are associated with adenoma detection (Table 3.1).

2) More specifically, we sought to examine the relationships between the adenoma detection rate and factors that likely impact it including: hours worked and number of procedures performed by the endoscopist on the day of the procedure prior to the index colonoscopy and adenoma detection.

\subsection{Hypothesis}

We hypothesized that increasing the number of hours worked and number of procedures performed prior to the index colonoscopy time per endoscopy session would be associated with decreased adenoma detection.

\subsection{Study design and site}

A retrospective cohort study was conducted using an endoscopy report database of individuals seen at the Montreal General Hospital (MGH) campus of the McGill University Health Center (MUHC), Montreal, Canada, a major tertiary care hospital in Montreal. Both surgeons and gastroenterologists staff the endoscopy service. On average, 11,000 colonoscopies and gastroscopies are performed annually, of which $75 \%$ were colonoscopies in 2008.

\subsection{Study population}

The study population included consecutive individuals who underwent CRC screening colonoscopy from June $1^{\text {st }}$ until August $25^{\text {th }} 2009$. For the 
purposes of this study, only individuals with Endoworks-generated colonoscopy reports were included. Excluded were individuals who underwent flexible sigmoidoscopy or colonoscopy where the indication was not CRC screening (e.g. bleeding, anemia, weight loss).

\subsection{Endoscopy database}

Endoworks is a computerized system that generates endoscopy reports and is capable of capturing endoscopic still images and videos (Endoworks, Olympus Corporation, Center valley, PA, USA); it is used for colonoscopies that are performed during regular working hours, Monday to Friday, from 8 am till $4 \mathrm{pm}$. Endoworks allows for capture of the immediate intra-colonoscopy unplanned events but not the down stream complications such as post polypectomy bleeding that can occur a few days after the colonoscopy.

Each endoscopist upon completion of the colonoscopy, enters data into the computer report that is electronically transmitted to a central data repository housed at the MUHC-MGH where it is kept secure. The endoscopy report has default fields that the endoscopist may either approve or choose from alternative options by drop down menu or by entering free text. Data include the patient's medical history as well as colonoscopy details including the type and amount of sedation administered, the comfort level of the patient during the colonoscopy, the quality of the colonoscopy preparation and the details of the colonoscopy (any abnormal findings, therapeutic or diagnostic interventions performed).

\subsection{Pathology reports}

Pathologists specialized in gastrointestinal pathology examined the histology of tissue/polyps obtained during colonoscopy and generated electronic reports that were stored in OACIS is an institutional electronic reporting data system. 


\subsection{Data abstraction}

Three trained research assistants abstracted data from the Endoworksgenerated colonoscopy reports of procedures that were performed during the study period as well as from the corresponding OACIS pathology reports. The research assistants entered the abstracted data into an electronic database (Microsoft Access).

\subsection{Data sources and variables of interest}

From the Endoworks generated endoscopy reports we obtained patient age, sex, family history of CRC, previous colonoscopy, prior polyp removal, CRC risk based on the endoscopist's judgment and knowledge of the patient's history. Events related to the colonoscopy were obtained including the number of polyps detected. The location and shape of polyps. In addition to cecal intubation, photo-documentation of the cecum, and incomplete colonoscopies. For incomplete colonoscopy (a procedure that fails to reach the cecum), the reason and the level of the colon reached were included. Quality of the bowel preparation was based on the endoscopist's subjective evaluation and was selected from a drop down menu in Endoworks; no scoring system was used although at least two are described in the litrature ${ }^{90,113}$. In addition the time spent by the endoscopist performing endoscopies (gastroscopies and colonoscopies) from the start of the endoscopy session and until the index colonoscopy, the number of colonoscopies, and the number of endoscopic procedures prior to the index colonoscopy were recorded. Colonoscopies that were performed between 8:00 and 12:00 were considered morning and those performed after 12:00 were considered afternoon.

From OACIS, data were obtained on whether the polyp removed was an adenoma or not. 
Table 3.1 Variables of interest.

\begin{tabular}{|c|c|c|c|c|}
\hline & $\begin{array}{l}\text { Source of } \\
\text { data }\end{array}$ & $\begin{array}{l}\text { Variables of } \\
\text { interest }\end{array}$ & Category & Values \\
\hline \multirow[t]{13}{*}{ Patient } & \multirow[t]{13}{*}{ Endoworks } & Sex & Binary & Male \\
\hline & & & & Female \\
\hline & & Age & Continuous & Years \\
\hline & & Previous & Binary & Yes \\
\hline & & colonoscopy & & No \\
\hline & & Prior polyp & Binary & Yes \\
\hline & & removal & & No \\
\hline & & Average risk for & Binary & Yes \\
\hline & & CRC & & No \\
\hline & & Family history of & Nominal & Yes \\
\hline & & CRC & & No \\
\hline & & & & HNPCC \\
\hline & & & & FAP \\
\hline \multirow[t]{12}{*}{ Colonoscopy } & & Incomplete & Binary & Yes \\
\hline & & colonoscopy & & No \\
\hline & & Cecal intubation & Binary & Yes \\
\hline & & & & No \\
\hline & & Photo- & Binary & Yes \\
\hline & & $\begin{array}{l}\text { documentation of } \\
\text { the cecum }\end{array}$ & & No \\
\hline & & Level reached & Ordinal & Sigmoid \\
\hline & & & & Descending \\
\hline & & & & Transverse \\
\hline & & & & Ascending \\
\hline & & & & Not mentioned \\
\hline & & $\begin{array}{l}\text { Reason for an } \\
\text { incomplete exam }\end{array}$ & Nominal & $\begin{array}{l}\text { Inadequate } \\
\text { preparation }\end{array}$ \\
\hline
\end{tabular}




\begin{tabular}{|c|c|c|}
\hline & & $\begin{array}{l}\text { Technical difficulty } \\
\text { Poor patient } \\
\text { tolerance } \\
\text { Not mentioned }\end{array}$ \\
\hline $\begin{array}{l}\text { Quality of the } \\
\text { bowel preparation }\end{array}$ & Ordinal & $\begin{array}{l}\text { Good } \\
\text { Fair } \\
\text { Poor } \\
\text { Not mentioned }\end{array}$ \\
\hline $\begin{array}{l}\text { Number of polyps } \\
\text { detected }\end{array}$ & Continuous & Discrete \\
\hline $\begin{array}{l}\text { Location of } \\
\text { polyps removed }\end{array}$ & Nominal & $\begin{array}{l}\text { Rectum } \\
\text { Recto-sigmoid } \\
\text { Sigmoid } \\
\text { Descending } \\
\text { Splenic flexure } \\
\text { Transverse } \\
\text { Hepatic flexure } \\
\text { Ascending } \\
\text { Cecum } \\
\text { lleocecal valve } \\
\text { Not mentioned }\end{array}$ \\
\hline $\begin{array}{l}\text { Shape of the } \\
\text { polyps detected }\end{array}$ & Nominal & $\begin{array}{l}\text { Sessile } \\
\text { Pedunculated } \\
\text { Not mentioned }\end{array}$ \\
\hline $\begin{array}{l}\text { Number of tattoos } \\
\text { performed to } \\
\text { mark sites of } \\
\text { suspicious polyps }\end{array}$ & Continuous & Discrete \\
\hline $\begin{array}{l}\text { Specialty of the } \\
\text { endoscopist }\end{array}$ & Binary & $\begin{array}{l}\text { Gastroenterology } \\
\text { Surgery }\end{array}$ \\
\hline Number of & Continuous & Discrete \\
\hline
\end{tabular}




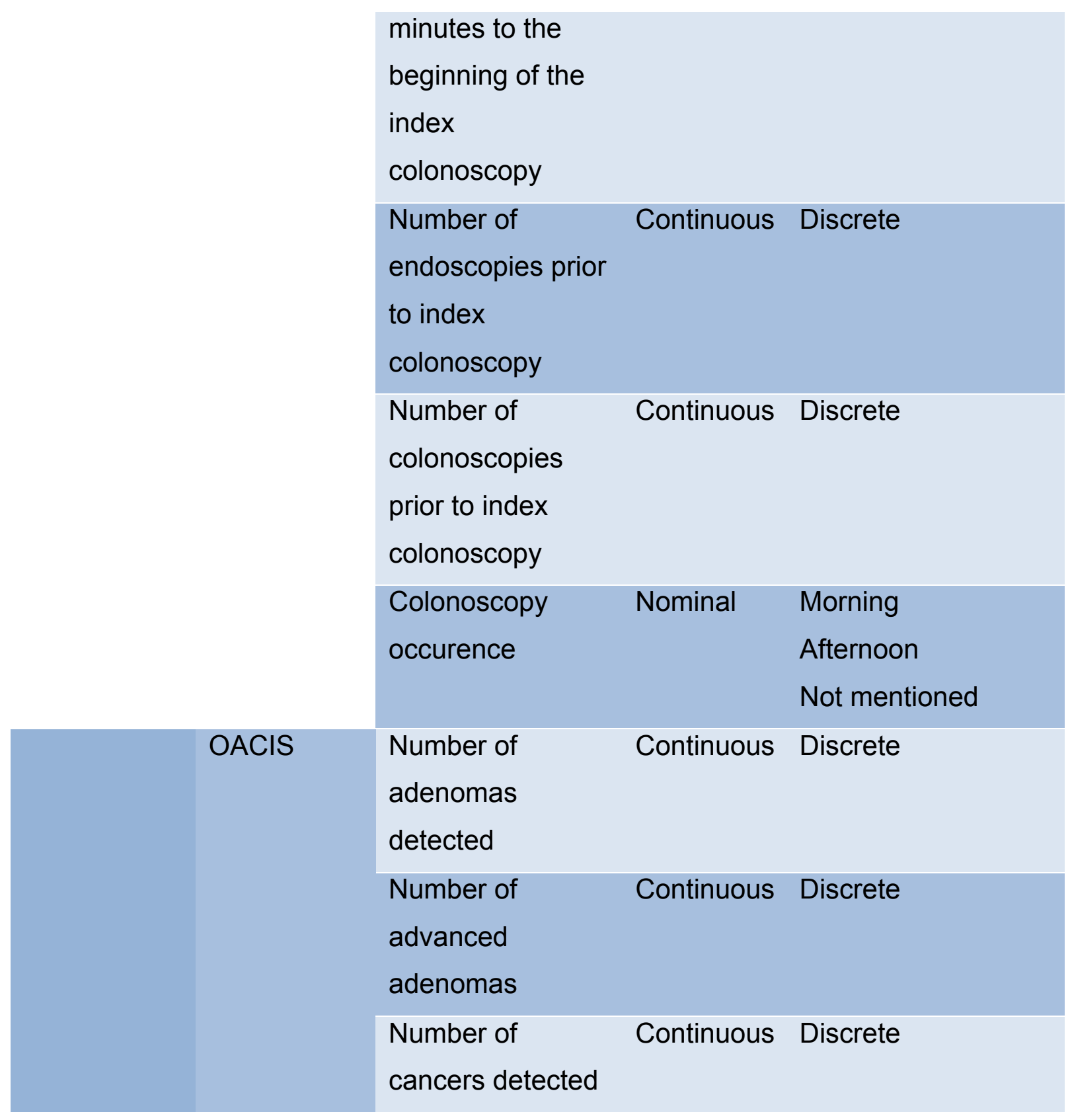

\subsection{Outcome variable}

Adenoma detection, a binary variable, was based on the pathology report, and defined as a colonoscopy where at least one adenoma was detected i.e. if a single adenoma was detected during a screening colonoscopy that would be as a positive outcome. 


\subsection{Sample size calculation}

Sample size calculation was based on a baseline adenoma occurrence in the population of $25 \%$, an a priori set confidence interval width of $+/-4 \%$, and a $95 \%$ confidence level. We used the formula below:

Sample size $=\left(Z^{2} \times P \times(1-P) / C^{2}\right.$

Where $Z=1.96$ for a confidence level $95 \%$

$\mathrm{P}=$ proportion of the outcome variable of interest (adenoma)

$C=$ confidence interval width (here $+/-0.04$ )

We calculated a needed sample size of 450 patients.

\subsection{Institution approval}

The Institutional Review Board at the McGill University Health Center approved the study.

\subsection{Method of data analysis}

Descriptive statistics were computed for continuous variables, means, standard deviations and minimum and maximum values were used; for categorical variables frequencies and interquartile ranges were used. Descriptive plots were used to illustrate bivariate relationships between selected independent variables and adenoma detection. Univariable and multivariable logistic regression were used to examine the association between independent variables and adenoma detection. Odds ratios (OR) and $95 \%$ confidence intervals $(\mathrm{Cl})$ were estimated. We examined how odds ratios changed as terms were added or subtracted from the model in order to identify any confounding between variables. We used the software $\mathrm{R}^{114}$ in our analysis.

A secondary analysis restricted to average risk individuals was performed to compare our results to those in the literature. 


\section{CHAPTER IV: RESULTS}

Over the 12-week period from June $1^{\text {st }}$ and until August $25^{\text {th }} 2009$, we identified 450 consecutive eligible patients who underwent screening colonoscopy. There were 20 duplicate entries that were excluded leaving a final sample size of 430 colonoscopy reports.

\subsection{Descriptive statistics}

The characteristics of the 430 patients included in this study are displayed in Table 4.1. Mean age was $63.4(\mathrm{SD}=10.9)$ years, there was a higher proportion of males compared to females $56.3 \%(95 \% \mathrm{Cl}, 51.4$ to 61.0$)$ vs. $43.7 \%(95 \% \mathrm{Cl}, 39.0$ to 48.6$)$ respectively, and $18.6 \%(95 \% \mathrm{Cl}, 15.0$ to 22.6) had a prior colonoscopy of whom $71.3 \%$ had a prior polypectomy. In total, $49.3 \%(95 \% \mathrm{Cl}, 44.5$ to 54.1$)$ of patients were at average risk for CRC while $50.7 \%(95 \% \mathrm{Cl}, 45.9$ to 55.5$)$ were at increased risk, $16 \%$ $(95 \% \mathrm{Cl}, 12.7$ to 19.9$)$ had a family history of $\mathrm{CRC}, 3(0.7 \%)$ individuals with hereditary nonpolyposis CRC (HNPCC), and $4(0.9 \%)$ patients with familial adenomatous polyposis (FAP).

The mean time from the beginning of the endoscopy session to the index colonoscopy was 164 minutes $(95 \% \mathrm{Cl}, 151.8$ to 175.6$)$ (range 0 to 450 minutes), the mean number of endoscopic procedures (gastroscopies and colonoscopies) prior to the index colonoscopy was $5.3(95 \% \mathrm{Cl}, 4.9$ to 5.7$)$ endoscopies and $3.8(95 \% \mathrm{Cl}, 3.4$ to 4.10$)$ colonoscopies. The majority of the colonoscopies were performed in the morning $70.9 \%(95 \% \mathrm{Cl}, 66.4$ to 75.2).

Over the study period the total number of colonoscopies performed by each physician ranged from 7 to 76 with a mean of 43 colonoscopies and the ADR varied from $15 \%$ to $48.5 \%$ with a mean of $27 \%$ (Table 4.2 ). 
Table 4.1 Patient and colonoscopy characteristics

\begin{tabular}{|c|c|c|}
\hline Variable & $\begin{array}{l}\text { Frequency } \\
(\mathrm{N}=430)\end{array}$ & $\begin{array}{l}\text { Percentage/mean } \\
\qquad(95 \% \mathrm{Cl})\end{array}$ \\
\hline \multicolumn{3}{|l|}{ Gender of patients } \\
\hline Male & 242 & 56.3 (51.4 to 61.0$)$ \\
\hline Female & 188 & 43.7 (39.0 to 48.6 ) \\
\hline Age in years (mean) & NA & $63.4(62.4$ to 64.4$)$ \\
\hline \multicolumn{3}{|l|}{ Previous colonoscopy } \\
\hline Yes & 80 & 18.6 (15.0 to 22.6 ) \\
\hline No & 350 & 81.4 (77.4 to 85.0$)$ \\
\hline \multicolumn{3}{|l|}{ Previous polyp removal } \\
\hline Yes & 57 & 13.3 (10.2 to 16.8$)$ \\
\hline No & 373 & 86.7 (83.2 to 89.8 ) \\
\hline \multicolumn{3}{|l|}{ Average risk } \\
\hline Yes & 212 & 49.3 (44.5 to 54.1$)$ \\
\hline No & 218 & 50.7 (45.9 to 55.5$)$ \\
\hline \multicolumn{3}{|l|}{ Family history of CRC } \\
\hline Yes & 69 & 16.0 (12.7 to 19.9$)$ \\
\hline No & 361 & 84.0 (80.1 to 87.3$)$ \\
\hline HNPCC & 3 & 0.7 (0.1 to 2.0$)$ \\
\hline FAP & 4 & $0.9(0.3$ to 2.4$)$ \\
\hline \multicolumn{3}{|l|}{ Colonoscopy variables } \\
\hline $\begin{array}{l}\text { Minutes to the beginning of the index } \\
\text { colonoscopy (mean) }\end{array}$ & NA & 163.7 (151.8 to 175.6$)$ \\
\hline $\begin{array}{l}\text { Number of endoscopies prior to } \\
\text { index colonoscopy (mean) }\end{array}$ & NA & 5.3 (4.9 to 5.7 ) \\
\hline $\begin{array}{l}\text { Number of colonoscopies prior to } \\
\text { index colonoscopy (mean) }\end{array}$ & NA & 3.8 (3.4 to 4.10$)$ \\
\hline
\end{tabular}


Table 4.2 Description of colonoscopies per physician

\begin{tabular}{lcccc} 
Physician & Physician sex & $\begin{array}{c}\text { Number of } \\
\text { colonoscopies }\end{array}$ & $\begin{array}{c}\text { Number of } \\
\text { adenomas } \\
\text { detected }\end{array}$ & $\begin{array}{c}\text { Adenoma detection rate* } \\
\text { (95\% Cl) }\end{array}$ \\
\hline MD 1 & Male & 58 & 18 & $31.0(19.5$ to 44.5$)$ \\
\hline MD 2 & Male & 76 & 14 & $18.4(10.5$ to 29.0$)$ \\
\hline MD 3 & Male & 33 & 16 & $48.5(30.8$ to 66.5$)$ \\
\hline MD 4 & Male & 33 & 5 & $15.2(1.9$ to 24.3$)$ \\
\hline MD 5 & Female & 7 & 2 & $28.6(3.7$ to 71.0$)$ \\
\hline MD 6 & Male & 51 & 12 & $23.5(12.8$ to 37.5$)$ \\
\hline MD 7 & Male & 75 & 19 & $25.3(16.0$ to 36.7$)$ \\
\hline MD 8 & Male & 40 & 6 & $15(5.7$ to 29.8$)$ \\
\hline MD 9 & Female & 24 & 6 & $25(9.8$ to 46.7$)$ \\
\hline MD 10 & Male & 33 & 13 & $39.4(22.9$ to 57.9$)$
\end{tabular}

* Defined as the number of colonoscopies where an adenoma was detected divided by the number of colonoscopies performed (these numbers are not adjusted according to age, sex, or previous colonoscopy).

The completion rate of colonoscopies was $96.3 \%(95 \% \mathrm{Cl}, 94.0$ to 97.9$)$; cecal intubation occurred in $95.8 \%(95 \% \mathrm{Cl}, 93.5$ to 97.5$)$, although photodocumentation was available for only $72.1 \%(95 \% \mathrm{Cl}, 67.6$ to 76.3$)$. The bowel preparation quality was rated as good in $86.3 \%(95 \% \mathrm{Cl}, 82.7$ to $89.4)$ of procedures, fair in $9.1 \%(95 \% \mathrm{Cl}, 6.5$ to 12.2$)$, poor in $3.7 \%$ $(95 \% \mathrm{Cl}, 2.1$ to 6.0$)$, and missing in $0.9 \%(95 \% \mathrm{Cl}, 0.3$ to 2.4$)$. Among all patients, the adenoma detection rate was $25.8 \%(95 \% \mathrm{Cl}, 21.7$ to 30.2$)$, polyp shape $83.2 \%(95 \% \mathrm{Cl}, 79.3$ to 86.6$)$, and location $68.7 \%$ $(95 \% \mathrm{Cl}, 64.1$ to 73.1$)$ were often not described (Table 4.3$)$. 
Table 4.3 Characteristics and findings of screening colonoscopies based on Endoworks.

\begin{tabular}{|c|c|c|}
\hline Variable & $\begin{array}{l}\text { Frequency } \\
(\mathrm{N}=430)\end{array}$ & $\begin{array}{c}\text { Percentage } \\
(95 \% \mathrm{Cl})\end{array}$ \\
\hline \multicolumn{3}{|l|}{ Incomplete colonoscopy ${ }^{a}$} \\
\hline Yes & 16 & $3.7(2.1$ to 6.0$)$ \\
\hline No & 414 & $96.3(94.0$ to 97.9$)$ \\
\hline \multicolumn{3}{|l|}{ Cecal Intubation } \\
\hline Yes & 412 & 95.8 (93.5 to 97.5$)$ \\
\hline No & 18 & $4.2(2.5$ to 6.5$)$ \\
\hline \multicolumn{3}{|c|}{ Photo-documentation of the cecum } \\
\hline Yes & 310 & 72.1 (67.6 to 76.3 ) \\
\hline No & 120 & 27.9 (23.7 to 32.4$)$ \\
\hline \multicolumn{3}{|l|}{ Bowel preparation quality } \\
\hline Good & 371 & 86.3 (82.7 to 89.4$)$ \\
\hline Fair & 39 & $9.1(6.5$ to 12.2$)$ \\
\hline Poor & 16 & $3.7(2.1$ to 6.0$)$ \\
\hline Don't know & 4 & 0.9 (0.3 to 2.4$)$ \\
\hline Total number of polyps & 428 & NA \\
\hline \multicolumn{3}{|c|}{ Adenoma detected on current colonoscopy } \\
\hline Yes & 111 & 25.8 (21.7 to 30.2$)$ \\
\hline No & 319 & $74.2(69.8$ to 78.3$)$ \\
\hline \multicolumn{3}{|l|}{ Polyp shape } \\
\hline Pedunculated & 17 & $4.0(2.3$ to 6.3$)$ \\
\hline Sessile & 55 & $12.8(9.8$ to 16.4$)$ \\
\hline Don't know & 356 & 83.2 (79.3 to 86.6$)$ \\
\hline \multicolumn{3}{|l|}{ Location of the polyp ${ }^{b}$} \\
\hline Rectum & 19 & $4.4(2.7$ to 6.8$)$ \\
\hline Recto-sigmoid junction & 12 & $2.8(1.5$ to 4.8$)$ \\
\hline Sigmoid & 32 & $7.5(5.2$ to 10.4$)$ \\
\hline Descending colon & 13 & $3.0(1.6$ to 5.1$)$ \\
\hline Splenic flexure & 0 & 0 \\
\hline Transverse colon & 23 & $5.4(3.4$ to 8.0$)$ \\
\hline Hepatic flexure & 4 & $0.9(0.3$ to 2.4$)$ \\
\hline Ascending colon & 19 & $4.4(2.7$ to 6.8$)$ \\
\hline cecum & 11 & 2.6 (1.3 to 4.6$)$ \\
\hline Ileocecal valve & 1 & $0.2(0.0$ to 1.3$)$ \\
\hline Don't know & 294 & 68.7 (64.1 to 73.1$)$ \\
\hline Tattoo & 0 & 0 \\
\hline Adenomas & 111 & $25.9(21.8$ to 30.4$)$ \\
\hline Cancer & 1 & $0.2(0.0$ to 1.3$)$ \\
\hline Advanced adenoma & 45 & 10.5 (7.8 to 13.8$)$ \\
\hline \multicolumn{3}{|l|}{ Timing of colonoscopy } \\
\hline Morning & 305 & 70.9 (66.4 to 75.2$)$ \\
\hline Afternoon & 124 & $28.8(24.6$ to 33.4$)$ \\
\hline Don't know & 1 & $0.2(0.0$ to 1.3$)$ \\
\hline
\end{tabular}


a. The discrepancy between the cecal intubation rate and the colonoscopy completion rate might be related incomplete documentation.

b. The percentage is from the 428 polyps detected. Location of only 134 polyps was described.

The reasons for incomplete colonoscopies as well as the level reached are displayed in table 4.4 .

Table 4.5 shows the tabulations of different variables with respect to the presence or absence of adenomas on colonoscopies.

There was a trend of increased adenoma detection in males $(30.6 \%$ vs. $19.7 \%)$, in patients who were at an increased risk for CRC (30.7\% vs. $20.8 \%$ ), in those who had a prior polypectomy ( 36.8 vs. $24.1 \%$ ), those who had a complete colonoscopy $(26.2 \%$, vs. $16.7 \%)$, picture documentation of the cecum $(29.4 \%$ vs. $16.7 \%)$, in those who had a good quality of bowel preparation compared to those with a fair or poor quality $(27.5 \%, 15.4 \%$, and $12.5 \%$ respectively), colonoscopies performed in the morning $(27.9 \%$ vs. $20.1 \%$ ), colonoscopies performed by female endoscopist (37.5 vs. $24.6)$, as well as colonoscopies performed by a gastroenterologist $(29.0 \%$ vs. $18.0 \%$ ). But all of these findings were inconclusive as the $95 \%$ confidence intervals overlapped.

We noticed that the percentage of adenomas detected increased with the increasing number of polyps detected per-colonoscopy (Figure 4.1), and decreased abruptly after 5.5 hours from the beginning of the endoscopy session (Figure 4.2), after 9 colonoscopies (Figure 4.3), and 12 endoscopies (Figure 4.4). 
Table 4.4 Reasons for an incomplete colonoscopy and the level reached in that exam.

$\begin{array}{lcc}\text { Incomplete colonoscopy } & \text { Frequency } & \text { Mean } \\ (\mathrm{N}=16) & (95 \% \mathrm{Cl})\end{array}$

Level reached in the exam

\begin{tabular}{llr} 
Ascending colon & 6 & $37.5(15.2$ to 64.6$)$ \\
\hline Transverse colon & 2 & $12.5(1.6$ to 38.3$)$ \\
Sigmoid & 6 & $37.5(15.2$ to 64.6$)$ \\
Unknown & 2 & $12.5(1.6$ to 38.3$)$ \\
Reason & & \\
\hline Inadequate preparation quality & 2 & $12.5(1.6$ to 38.3$)$ \\
Technical difficulty & 6 & $37.5(15.2$ to 64.6$)$ \\
Poor patient tolerance & 3 & $18.8(4.0$ to 45.6$)$ \\
Not mentioned & 5 & $31.3(11.0$ to 58.7$)$
\end{tabular}


Table 4.5 Variables with regard to adenoma detection and the percentage of adenomas detected.

\begin{tabular}{|c|c|c|c|}
\hline & $\begin{array}{l}\text { Adenoma } \\
(\mathrm{N}=111)\end{array}$ & $\begin{array}{c}\text { No } \\
\text { adenoma } \\
(\mathrm{N}=319)\end{array}$ & $\begin{array}{l}\text { Percentage of } \\
\text { adenomas } \\
(95 \% \mathrm{Cl})\end{array}$ \\
\hline \multicolumn{4}{|l|}{ Patient sex } \\
\hline Male & 74 & 168 & 30.6 (24.8 to 36.8 ) \\
\hline Female & 37 & 151 & 19.7 (14.2 to 26.1$)$ \\
\hline \multicolumn{4}{|l|}{ History of colonoscopy } \\
\hline Previous colonoscopy & 22 & 58 & 27.5 (18.1 to 38.6$)$ \\
\hline No previous colonoscopy & 89 & 261 & 25.4 (20.9 to 30.3 ) \\
\hline \multicolumn{4}{|l|}{ Risk of CRC } \\
\hline Average risk & 44 & 168 & 20.8 (15.5 to 26.8 ) \\
\hline Increased risk & 67 & 151 & 30.7 (24.7 to 37.3$)$ \\
\hline \multicolumn{4}{|l|}{ Family history of CRC } \\
\hline Family history & 18 & 51 & 26.1 (16.3 to 38.1$)$ \\
\hline No family history & 93 & 268 & 25.8 (21.3 to 30.6$)$ \\
\hline \multicolumn{4}{|c|}{ History of prior polypectomy } \\
\hline Previous polypectomy & 21 & 36 & 36.8 (24.4 to 50.7 ) \\
\hline No previous polypectomy & 90 & 283 & 24.1 (19.9 to 28.8$)$ \\
\hline \multicolumn{4}{|l|}{ Colonoscopy extent } \\
\hline Complete colonoscopy & 108 & 304 & 26.2 (22.0 to 30.7$)$ \\
\hline Incomplete colonoscopy & 3 & 16 & 18.8 (4.0 to 45.6$)$ \\
\hline \multicolumn{4}{|l|}{ Preparation quality } \\
\hline Good & 102 & 269 & 27.5 (23.0 to 32.3$)$ \\
\hline Fair & 6 & 33 & 15.4 (5.8 to 30.5$)$ \\
\hline Poor & 2 & 14 & $12.5(1.6$ to 38.3$)$ \\
\hline Don't know & 1 & 3 & 25 (0.6 to 80.6 ) \\
\hline
\end{tabular}




\begin{tabular}{|c|c|c|c|}
\hline \multicolumn{4}{|c|}{ Picture documentation of the cecum } \\
\hline Documented & 91 & 219 & 29.4 (24.3 to 34.8$)$ \\
\hline Not documented & 20 & 100 & 16.7 (10.5 to 24.6$)$ \\
\hline \multicolumn{4}{|l|}{ Shape of the polyp } \\
\hline Pedunculated polyp & 15 & 2 & 88.2 (63.6 to 98.5$)$ \\
\hline Sessile polyp & 29 & 26 & 52.7 (38.8 to 66.3 ) \\
\hline Not described & 67 & 291 & 18.7 (14.8 to 23.1$)$ \\
\hline \multicolumn{4}{|c|}{ Timing of endoscopy } \\
\hline Morning session & 85 & 220 & 27.9 (22.9 to 33.3 ) \\
\hline Afternoon session & 25 & 99 & 20.1 (13.5 to 28.3 ) \\
\hline Unknown & 1 & 0 & NA \\
\hline \multicolumn{4}{|l|}{ Endoscopist sex } \\
\hline Male & 96 & 294 & 24.6 (20.4 to 29.2$)$ \\
\hline Female & 15 & 25 & 37.5 (22.7 to 54.2$)$ \\
\hline \multicolumn{4}{|c|}{ Specialty of endoscopist } \\
\hline Gastroenterology & 91 & 223 & 29.0 (24.0 to 34.3$)$ \\
\hline Surgery & 20 & 91 & 18.0 (11.4 to 26.4$)$ \\
\hline
\end{tabular}


Figure 4.1 The percentage of adenomas detected increases as the number of polyps detected increases

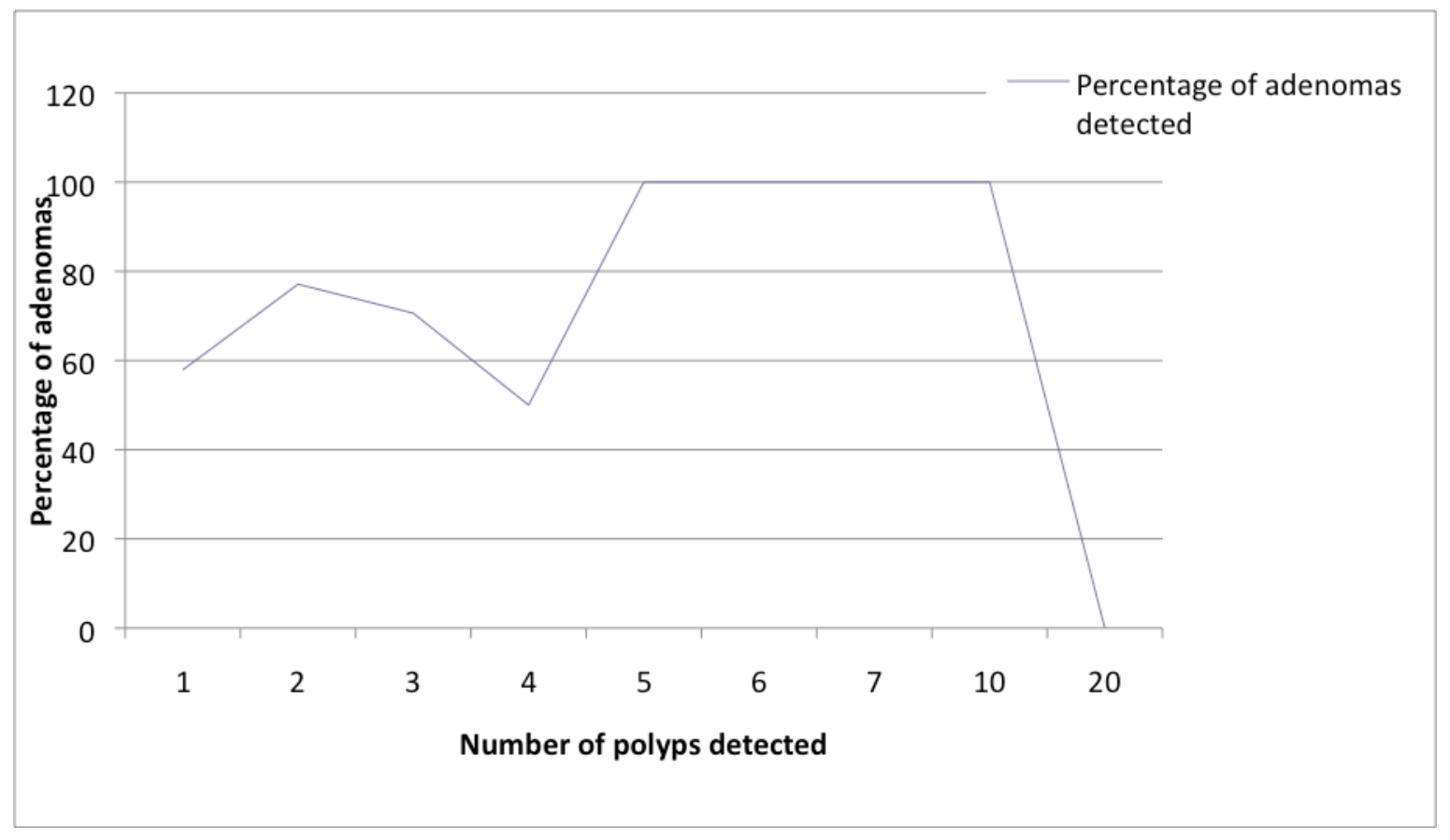

Figure 4.2 The percentage of adenomas detected decreases as the time (in hours) from the beginning of the endoscopy session increases 


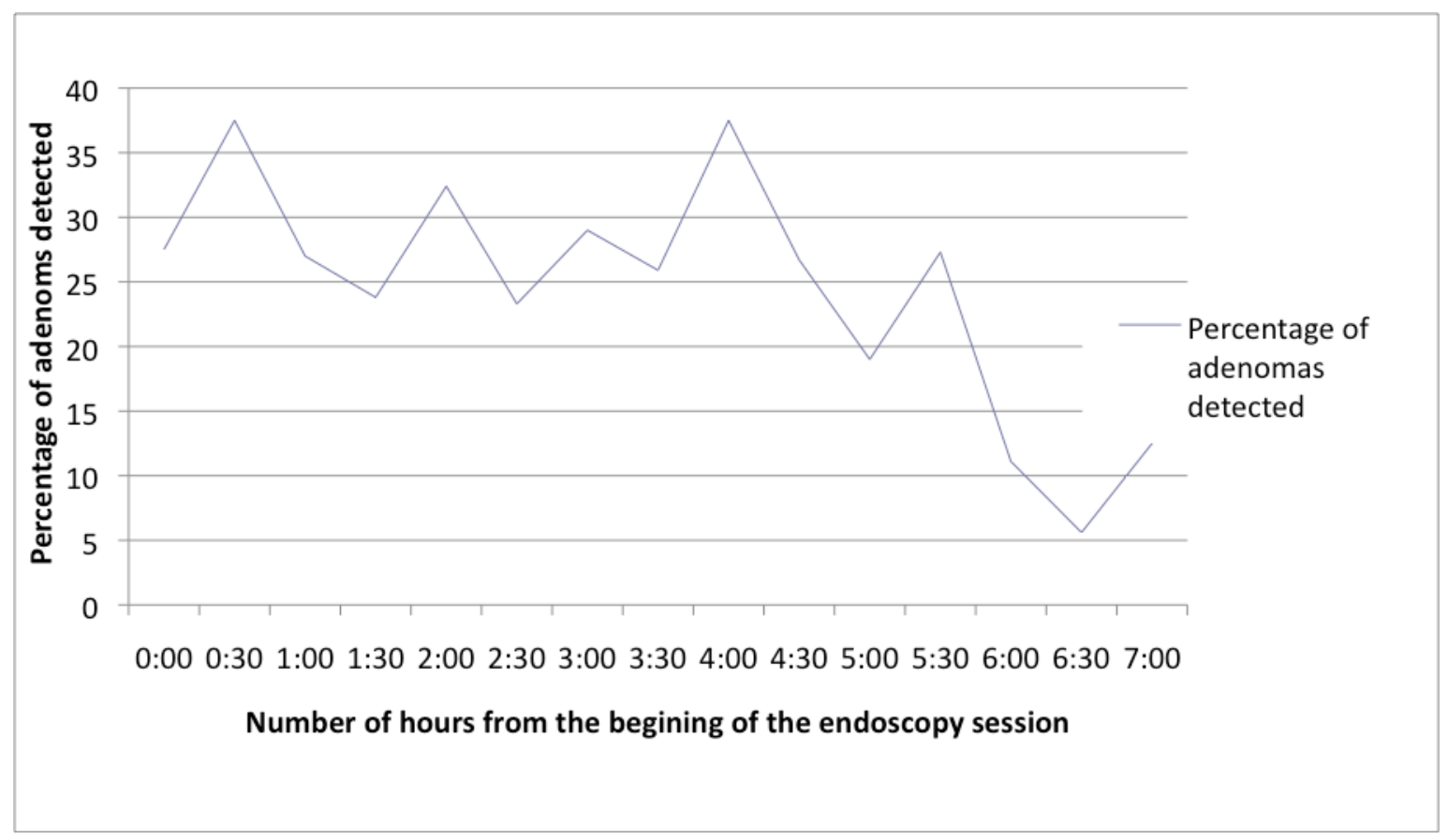

Figure 4.3 Percentage of adenomas detected in relation to the sequence of index colonoscopy in relation to the number of colonoscopies

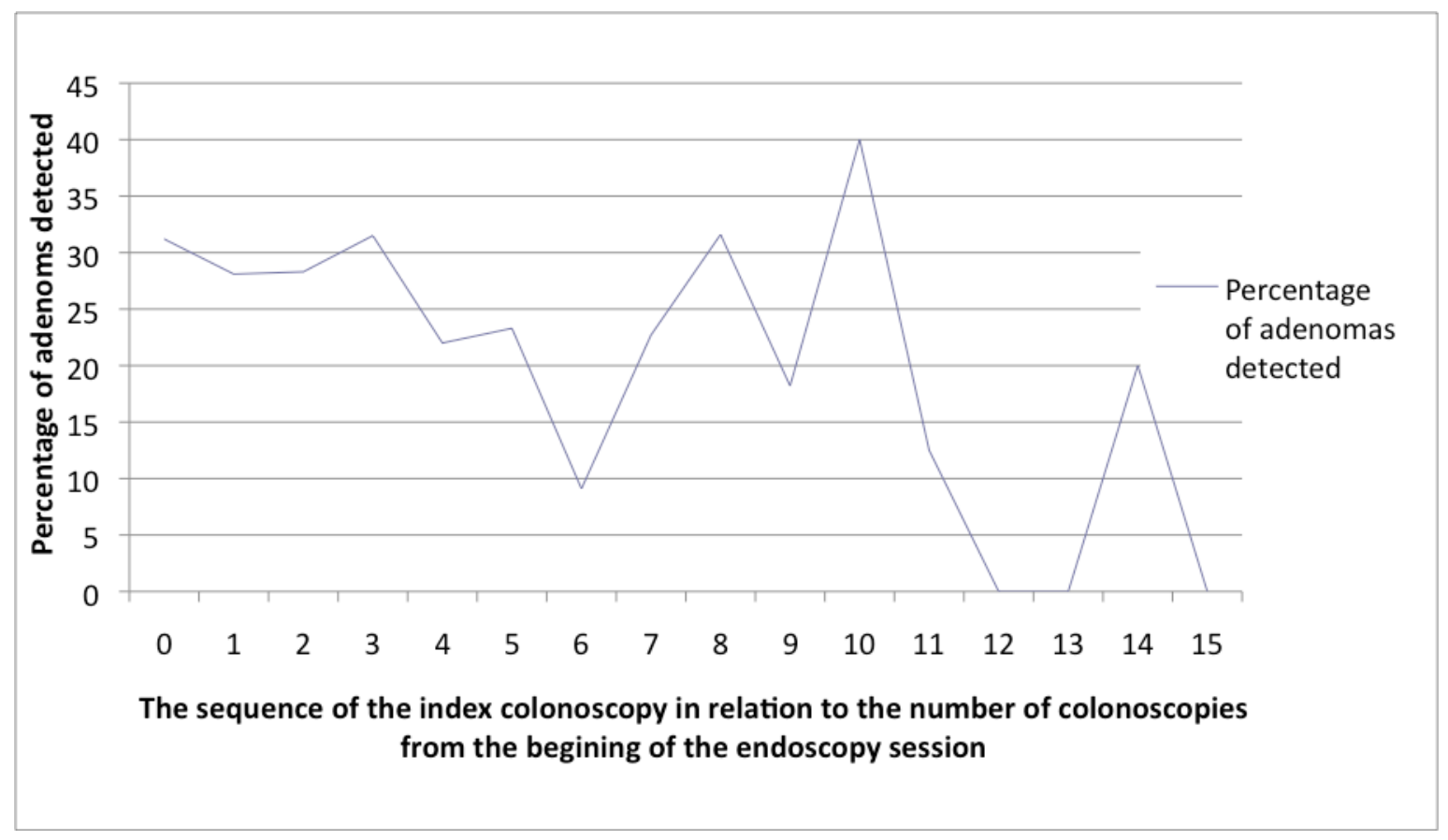

Figure 4.4 Percentage of adenomas detected in relation to the sequence of index colonoscopy in relation to the number of endoscopies 


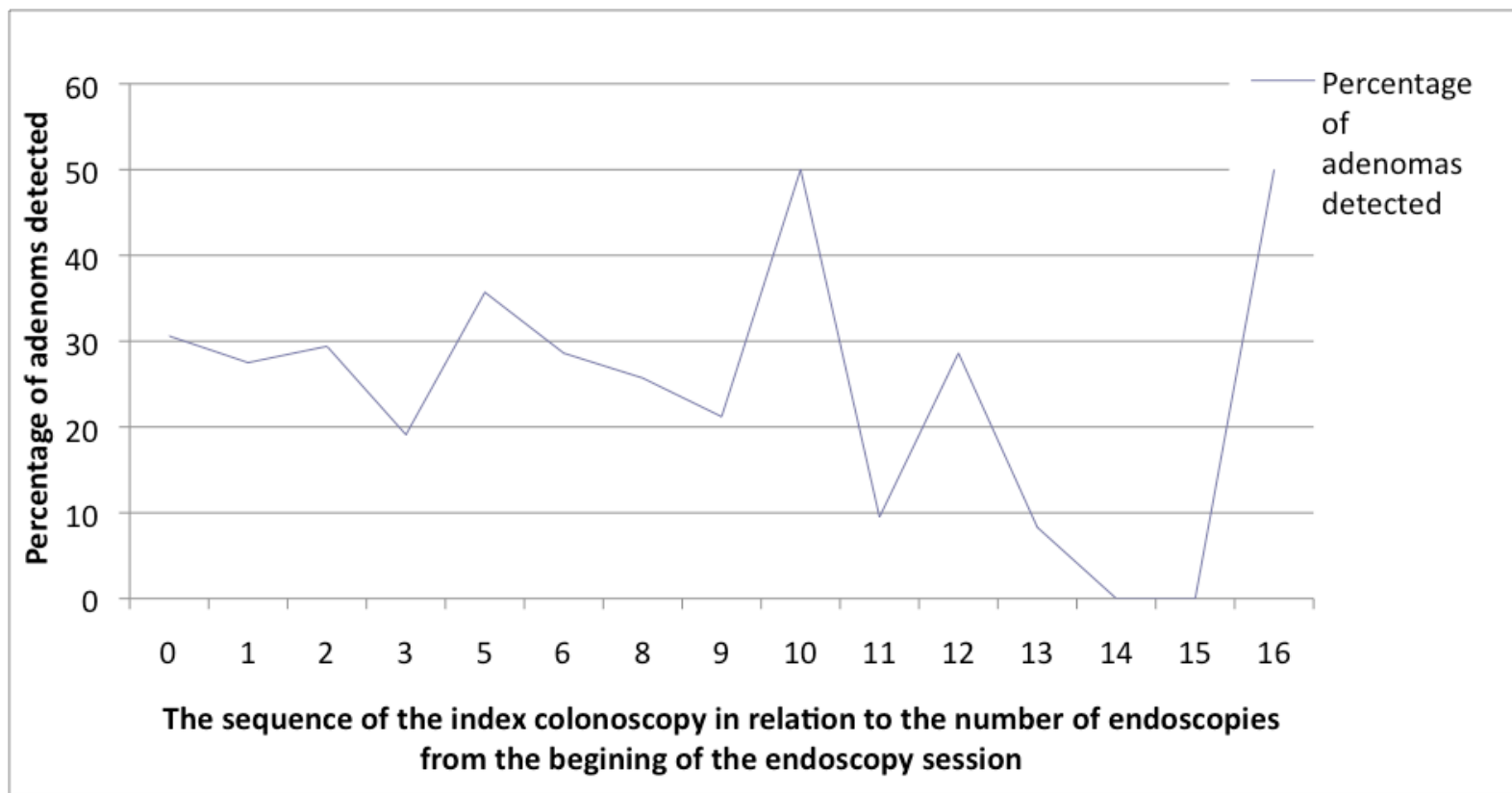




\subsection{Examining descriptive graphs}

The age of the patients who underwent screening colonoscopies was normally distributed (Figure 4.5). Male endoscopists performed colonoscopies on a population with a much broader age span compared to female endoscopists (figure 4.6).

As the quality of the bowel preparation decreased the number of polyps detected decreased (figure 4.7). Comparing the good and poor quality of bowel preparation, the poor quality preparation colonoscopies tended to start later in the endoscopy session compared to the good quality bowel preparation (figure 4.8). Numerous other descriptive graphs are included in the appendix (chapter VI).

Using the pairs function in $\mathrm{R}$ (figure 4.9), we notice collinearity between minutes to endoscopy, sequence of colonoscopy in relation to all endoscopies as well as in relation to colonoscopies, which occurred because these variables are measuring a similar construct. Thus we will only use minutes to endoscopy in the following segments. 
Figure 4.5 Age distribution of the patients who underwent screening colonoscopy.

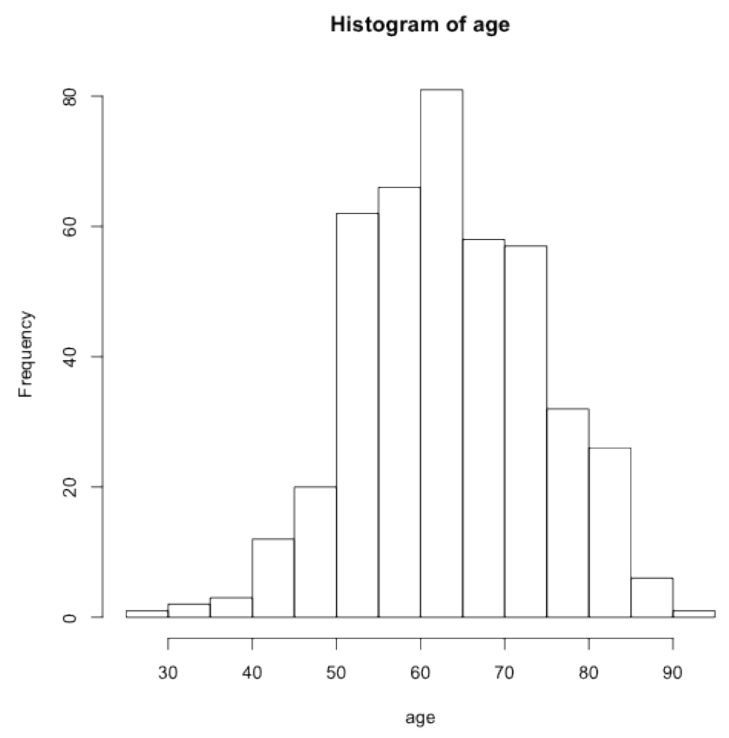

Figure 4.6 Box plot of age of patients based on the gender of the endoscopist

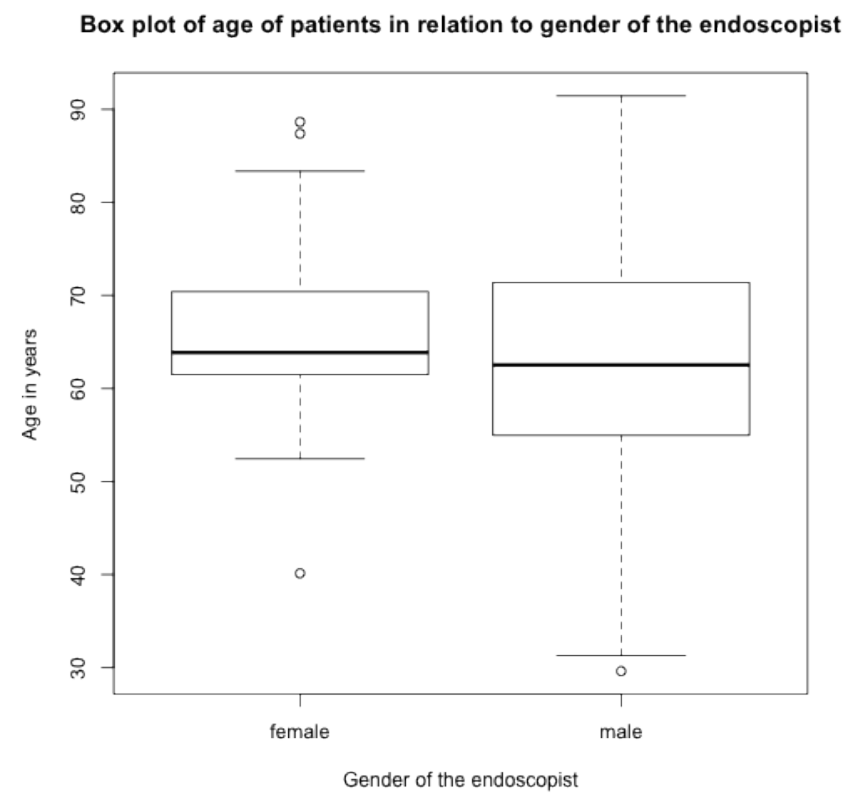


Figure 4.7 Box plot of the number of polyps detected in relation to the quality of the bowel preparation.

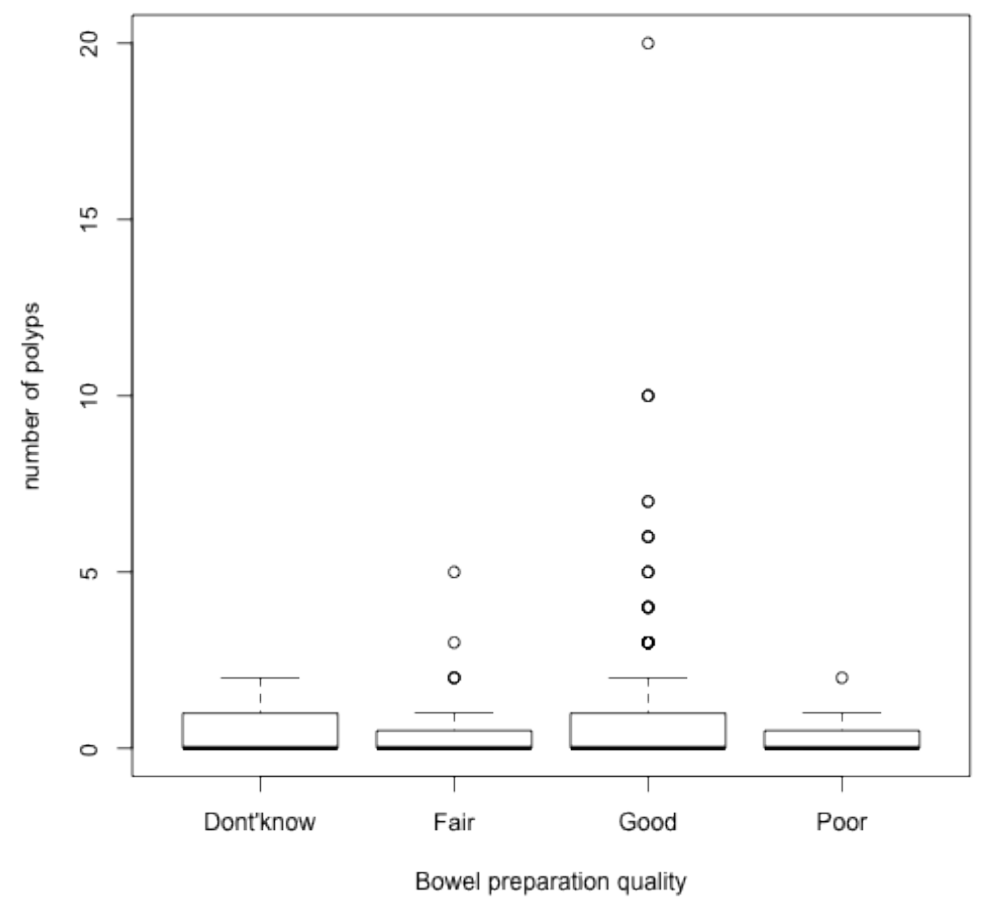

Figure 4.8 Box plot of the quality of the bowel preparation in relation to the time till the start of the index colonoscopy from the beginning of the endoscopy session.

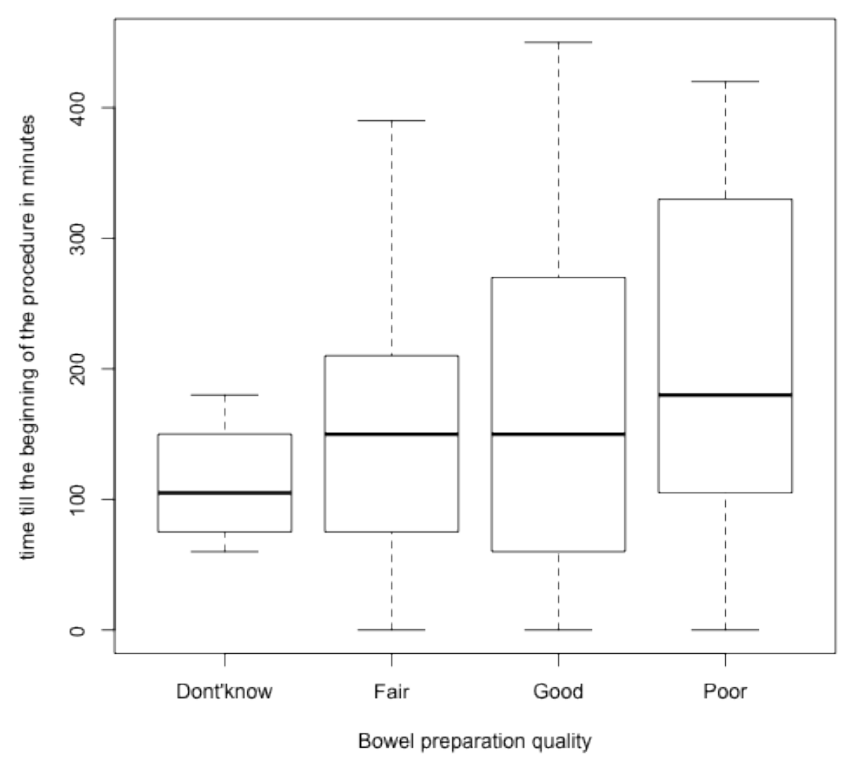


Figure 4.9 Pairs function in $\mathrm{R}$ to investigate confounding.

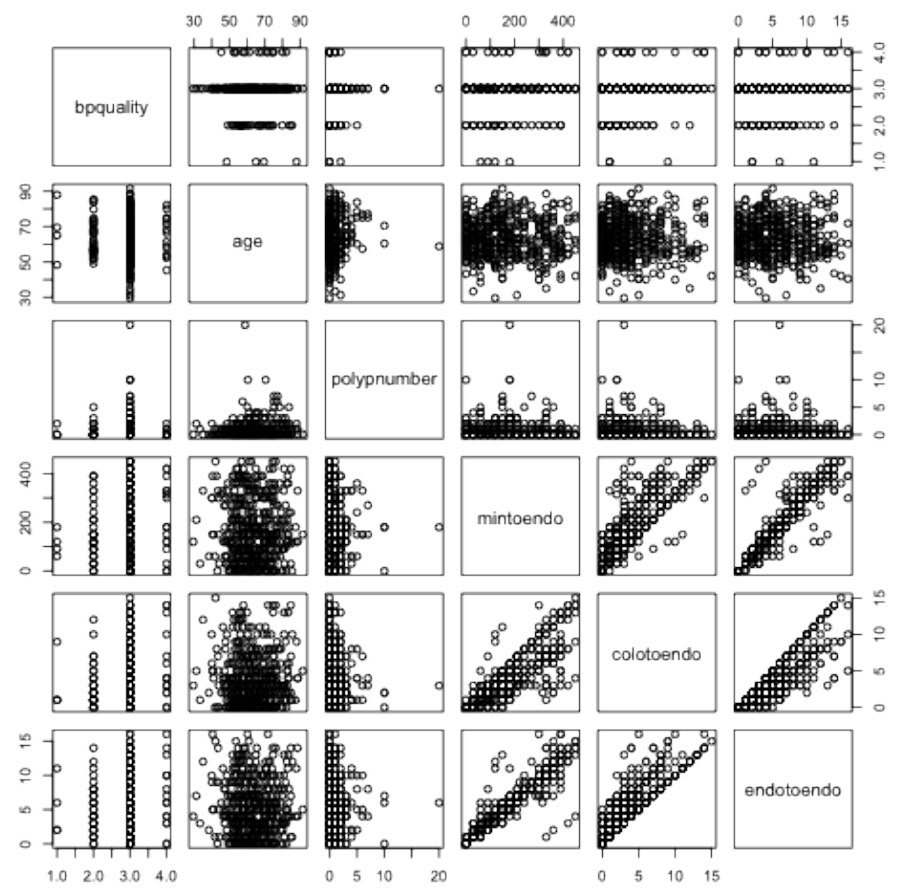

\subsection{Univariable and multivariable model}

Results of the univariable analysis are shown in table 4.6.

The evidence was inconclusive for the effect of prior colonoscopy (OR $1.11,95 \% \mathrm{Cl}, 0.64$ to 1.92$)$, family history of $\mathrm{CRC}(\mathrm{OR} 1.02,95 \% \mathrm{Cl}, 0.57$ to 1.83 ), incomplete colonoscopy (OR $1.44,95 \% \mathrm{Cl}, 0.13$ to 16.05 ), cecal intubation (OR $1.78,95 \% \mathrm{Cl}, 0.50$ to 6.26 ), quality of the bowel preparation, and endoscopist sex (OR $0.54,95 \% \mathrm{Cl}, 0.28$ to 1.07) on the detection of adenomas. There was an increased odds of detecting adenomas when the patient was male (OR $1.80,95 \% \mathrm{Cl}, 1.14$ to 2.82$)$, for every 1 -year increase in age (OR $1.04,95 \% \mathrm{Cl}, 1.02$ to 1.06 ), previous polyp removal (OR $1.83,95 \% \mathrm{Cl}, 1.02$ to 3.30 ), photo-documentation of the cecum (OR $2.08,95 \% \mathrm{Cl}, 1.21$ to 3.56 ), and with increasing number of polyps (OR $3.74,95 \% \mathrm{Cl}, 2.76$ to 5.06 ). The detection of adenomas was decreased in patients who were at average risk for CRC (OR 0.59, 95\% Cl, 
0.38 to 0.92 ), with each increased hour from the beginning of the endoscopy session to the index colonoscopy (OR $0.87,95 \% \mathrm{Cl}, 0.78$ to 0.97), with each colonoscopy performed prior to the index colonoscopy (OR $0.93,95 \% \mathrm{Cl}, 0.87$ to 0.99 ), with each endoscopy (colonoscopy and gastroscopy) prior to the index colonoscopy (OR $0.95,95 \% \mathrm{Cl}, 0.90$ to 1.00 ), and when the colonoscopy was performed by a surgeon (OR 0.51 , $95 \% \mathrm{Cl}, 0.30$ to 0.88$)$.

When multivariable modeling was conducted all the point estimates as well as the confidence intervals changed and in general got substantially wider suggesting confounding (table 4.6).

We used the BIC command in $\mathrm{R}$ to create formatted output to compare coefficients between different models and found confounding between:

1- Male gender and family history.

2- Male gender and average risk.

3- Age and polyp number.

4- Age and family history.

When the analysis was limited to average risk patients only (212), there was an increased odds of detecting adenomas when the patient was male (OR 2.74, 95\% Cl, 1.27 to 5.91), for every 1-year increase in age (OR 1.06, $95 \% \mathrm{Cl}, 1.02$ to 1.11 ), and with increasing number of polyps (OR 2.14, $95 \% \mathrm{Cl}, 1.56$ to 2.93$)$. The detection of adenomas was decreased with every colonoscopy performed prior to the index colonoscopy (OR 0.84 , $95 \% \mathrm{Cl}, 0.74$ to 0.95 ), with each endoscopy (colonoscopy and gastroscopy) prior to the index colonoscopy (OR $0.88,95 \% \mathrm{Cl}, 0.80$ to 0.97 ), and with each increased hour from the beginning of the endoscopy session to the index colonoscopy (OR $0.80,95 \% \mathrm{Cl}, 0.67$ to 0.95 ). When the analysis is restricted to average risk individuals on multivariate analysis, male gender was associated with increased adenoma detection OR $3.52(95 \% \mathrm{Cl}, 1.31$ to 9.42$)$ and the risk associated with increasing number of polyps detected was less pronounced OR $2,14(95 \% \mathrm{Cl}, 1.44$ to 
$3,19)$ and the effect of the number of hours till the index colonoscopy was inconclusive OR $0.67(95 \% \mathrm{Cl}, 0.33$ to 1.27$)$ (table 4.7$)$. 
Table 4.6 Results of univariable and multivariable modeling for detection of at least one adenoma on screening colonoscopy. $(N=430)$

\begin{tabular}{|c|c|c|}
\hline Variable & $\begin{array}{c}\text { Univariable models } \\
\text { Odds ratios }\end{array}$ & $\begin{array}{l}\text { Multivariate model } \\
\text { Adjusted odds ratios }\end{array}$ \\
\hline Male patient & 1.80 (1.14 to 2.82$)$ & 1.67 (0.91 to 3.04$)$ \\
\hline Age & $1.04(1.02$ to 1.06$)$ & 1.04 (1.02 to 1.07$)$ \\
\hline Prior colonoscopy & $1.11(0.64$ to 1.92$)$ & 0.67 (0.28 to 1.59$)$ \\
\hline Average risk & 0.59 (0.38 to 0.92$)$ & $0.71(0.33$ to 1.50$)$ \\
\hline Family history & 1.02 (0.57 to 1.83$)$ & 1.89 (0.72 to 4.89$)$ \\
\hline Incomplete colonoscopy & $1.44(0.13$ to 16.05$)$ & $1.36(0.03$ to 57.86$)$ \\
\hline Previous polyp removed & $1.83(1.02$ to 3.30$)$ & 1.60 (0.58 to 4.43$)$ \\
\hline Cecum intubated & $1.78(0.50$ to 6.26$)$ & $1.10(0.20$ to 5.99$)$ \\
\hline \multicolumn{3}{|l|}{ Bowel preparation quality } \\
\hline Good & $1.14(0.12$ to 11.06$)$ & 2.17 (0.07 to 67.48$)$ \\
\hline Fair & 0.55 (0.05 to 6.16$)$ & 1.31 (0.04 to 47.08$)$ \\
\hline Poor & $0.43(0.03$ to 6.41$)$ & 1.21 (0.03 to 57.07$)$ \\
\hline $\begin{array}{l}\text { Photo-documentation of the } \\
\text { cecum }\end{array}$ & 2.08 (1.21 to 3.56$)$ & 0.92 (0.39 to 2.19$)$ \\
\hline Polyp number & 3.74 (2.76 to 5.06$)$ & $3.71(2.70$ to 5.10$)$ \\
\hline \multicolumn{3}{|l|}{ Time to colonoscopy } \\
\hline Hours to colonoscopy & 0.87 (0.78 to 0.97$)$ & 0.51 (0.31 to 0.79$)$ \\
\hline $\begin{array}{l}\text { Number of colonoscopies to the } \\
\text { index colonoscopy }\end{array}$ & 0.93 (0.87 to 0.99$)$ & $0.99(0.81$ to 1.21$)$ \\
\hline $\begin{array}{l}\text { Number of endoscopic } \\
\text { procedures to the index } \\
\text { colonoscopy }\end{array}$ & 0.95 (0.90 to 1.00$)$ & 1.18 (0.91 to 1.52$)$ \\
\hline Endoscopy in the morning & 4.96 e-07 (0 to Inf) & $0.32(0.10$ to 1.04$)$ \\
\hline Male endoscopist & 0.54 (0.28 to 1.07$)$ & $0.65(0.25$ to 1.65$)$ \\
\hline Surgical specialty of endoscopist & $0.51(0.30$ to 0.88$)$ & $0.89(0.38$ to 2.06$)$ \\
\hline
\end{tabular}


Table 4.7 Results of univariable and multivariable modeling for detection of an adenoma on screening colonoscopy when the analysis was restricted to average risk patients $(\mathrm{N}=212)$.

\begin{tabular}{|c|c|c|}
\hline Variable & $\begin{array}{l}\text { Univariable models } \\
\text { Odds ratios }\end{array}$ & $\begin{array}{l}\text { Multivariate model } \\
\text { Adjusted odds ratios }\end{array}$ \\
\hline Male patient & $2.74(1.27$ to 5.91$)$ & $3.52(1.31$ to 9.42$)$ \\
\hline Age & $1.06(1.02$ to 1.11$)$ & $1.10(1.04$ to 1.16$)$ \\
\hline Prior colonoscopy & $1.40(0.55$ to 3.56$)$ & 1.09 (0.29 to 4.09$)$ \\
\hline Previous polyp removed & 8275680 (0 to Inf) & $1.11 \mathrm{e}+6(0$ to $\operatorname{lnf})$ \\
\hline Cecum intubated & $1.19(0.25$ to 5.71$)$ & $0.70(0.06$ to 7.65$)$ \\
\hline \multicolumn{3}{|l|}{ Bowel preparation quality } \\
\hline Good & 6.04 (0.79 to 46.37$)$ & $2.94(0.34$ to 25.38$)$ \\
\hline Poor & $2.22(0.12$ to 39.63$)$ & $2.74(0.10$ to 76.97$)$ \\
\hline $\begin{array}{l}\text { Photo-documentation of the } \\
\text { cecum }\end{array}$ & 2.02 (0.88 to 4.64$)$ & 2.25 (0.57 to 8.91$)$ \\
\hline Polyp number & 2.14 (1.56 to 2.93$)$ & 2.14 (1.44 to 3.19$)$ \\
\hline \multicolumn{3}{|l|}{ Time to colonoscopy } \\
\hline Hours to colonoscopy & 0.80 (0.67 to 0.95$)$ & $0.67(0.33$ to 1.27$)$ \\
\hline $\begin{array}{l}\text { Number of colonoscopies to the } \\
\text { index colonoscopy }\end{array}$ & $0.84(0.74$ to 0.95$)$ & $0.92(0.64$ to 1.32$)$ \\
\hline $\begin{array}{l}\text { Number of endoscopic } \\
\text { procedures to the index } \\
\text { colonoscopy }\end{array}$ & 0.88 (0.80 to 0.97$)$ & 0.93 (0.65 to 1.35$)$ \\
\hline Endoscopy in the morning & $1.94(0.87$ to 4.32$)$ & $0.23(0.03$ to 1.65$)$ \\
\hline Male endoscopist & $0.41(0.16$ to 1.05$)$ & $0.43(0.11$ to 1.59$)$ \\
\hline Surgical specialty of endoscopist & $0.76(0.35$ to 1.65$)$ & $2.76(0.76$ to 10.00$)$ \\
\hline
\end{tabular}




\section{CHAPTER V: DISCUSSION}

\subsection{Discussion}

Gastrointestinal endoscopy is essential to digestive health care and CRC screening is a large component of that care with significant resources allocated to it. This study aimed to identify variables related to adenoma detection on screening colonoscopy in order to optimize the detection of adenomas and, thereby, improve colonoscopy as a screening tool for CRC. The age range of patients included in our study was wider than that recommended for average risk screening due to including patients at increased risk for CRC.

We found that fewer polyps and adenomas were detected as the time to the index colonoscopy increased, this might be due to operator fatigue, pressure for keeping the procedure scheduling on time, poorer bowel preparation or a combination of these factors. Our results are in keeping with those of prior studies showing that the polyp detection rate decreased with time ${ }^{111}$. For example, in one study insertion time, defined as time spent from the introduction of the colonoscope through the anus until reaching the end of the colon, increased as time progressed from the beginning of the endoscopy session ${ }^{115}$, suggesting endoscopist fatigue. Because the majority of the patients in our study received conscious sedation, we did not evaluate this factor because of the lack of variability.

A study found that deep sedation was associated with an increased detection of polyps $>9 \mathrm{~mm}$ in size, the calculated number needed to screen for the detection of an advanced lesion would be 141 patients under deep sedation, which was not clinically acceptable given the risks associated with the administration of deep sedation by the endoscopist, or the cost associated with the involvement of an anesthesiologist ${ }^{116}$. We could not evaluate the level of sedation achieved throughout the colonoscopy due to the retrospective nature of the study. 
A variant definition of the ADR is the proportion of adenomas detected per patient ${ }^{117}$. Our definition of the ADR does not account for the presence of more than one adenoma per patient, which might be a shortcoming; nonetheless, we opted to use the definition we had stated because of its broad adoption in the literature which permitted comparing our results with other studies ${ }^{110,118}$. The ADR in our study was comparable to others ${ }^{50-52}$, however it varied greatly between endoscopists, but by the same token so did the patient characteristics they screened (age, risk for the development of CRC, previous colonoscopy...), and the number of procedures they performed. We found that male endoscopists performed colonoscopies on a population with a much broader age range compared to female endoscopists. This might have inflated the ADR for female endoscopists as their patients were expected to have a higher prevalence of adenomas as adenomas increase with age.

More adenomas were detected in male patients, those with a prior history of a polypectomy, and in those with good quality of bowel preparation; all of these factors are known to be associated with an increased $A D R^{51,87-89}$. In addition, there was increased adenomas detection in the colonoscopies with photo-documentation of the cecum, for which we have no explanation; this would require further investigation. One possible explanation might be the personality of the endoscopist with those who photo-document the cecum may be more meticulous. We cannot, however, exclude other explanations dependent on variables that we did not account for in our study.

On univariable analysis, adenoma detection was higher in patients that were judged by the endoscopist to be at increased risk but the evidence was inconclusive on the multivariable analysis. Although the adenoma detection rate has been advocated as a quality indicator for colonoscopies we think that using a cut-off value is an oversimplification. This is due to that even when we limit this indicator to average risk patients the detection of adenomas varies with age, and varies even between the index 
colonoscopy and individuals who had already had one or two prior colonoscopies.

There are numerous studies that have demonstrated that increased withdrawal time is associated with an increased $A D R^{49,50,95}$. We did not have withdrawal times for the colonoscopies for most endoscopists, as time recording has not yet been implemented in a standardized way. In a recent retrospective study where time recording was implemented there was a statistically non-significant increase in polyps detected, and these were mostly small non-adenomatous polyps with no cancer potential ${ }^{120}$. We think that the withdrawal times represents a characteristic of the endoscopist and the degree of care and scrutiny that he/she takes in examining the colon, definitely taking less time in the examination will not aid in detecting more adenomas, but by merely increasing the time without other associated procedural characteristics we do not expect that the ADR would increase in a predictable fashion. Furthermore, the effect of the withdrawal time is expected to be variable when the time is spent on examining a segment of the colon as opposed to the whole colon ${ }^{121}$. Other issues raised about withdrawal times include the subjective threshold of 6 minutes that has become the cutoff value used in these studies ${ }^{122,123}$. In addition it seems that the slower, more patient and meticulous the endoscopist is, the higher the ADR and rather than a dichotomized variable the withdrawal time is more likely a continues one ${ }^{117}$.

One of the limitations of the study is that we did not have the date of the prior colonoscopy in patients with prior procedures, thus, those who had a colonoscopy a year prior to the current exam and had a repeated colonoscopy due to a suboptimal cleansing bowel preparation might have exhibited a lower probability for adenoma when compared to a person who had undergone colonoscopy 10 years prior.

On univariable analysis there was a higher probability of detecting adenomas in male patients, with increasing age, in those who had a prior polyp removed, when there was photo-documentation of the cecum, and 
as the number of polyps detected during a colonoscopy increases. In contrast, there was a lesser probability of detecting adenomas in those at average risk for $\mathrm{CRC}$, when the colonoscopy was performed by a surgeon, and with an increasing number of endoscopies and colonoscopies before the index colonoscopy, and as the time from the beginning of the endoscopy session till the index colonoscopy increased. The results for other variables were inconclusive.

On multivariable analysis almost all the variables point estimates and confidence intervals changed, reflecting confounding. The finding of confounding is not unexpected as these variables are correlated, for example adenomas increase with age, those with a family history of CRC have an increased risk for developing adenomas, and older subjects are more likely to have had a colonoscopy with or without polyps being removed.

After multivariable analysis, variables that were associated with increased adenoma detection were increasing age of the patients (in years) OR 1.04 (95\% Cl, 1.02 to 1.07$)$, increased polyp number OR $3.71(95 \% \mathrm{Cl}, 2.70$ to $5.10)$, while there was a decreased probability of detecting an adenoma with greater elapsed time (in hours) from the beginning of the endoscopy session till the index colonoscopy OR $0.51(95 \% \mathrm{Cl}, 0.31$ to 0.79$)$. When the analysis was limited to average risk individuals, similar variables were associated with the detection of adenomas apart from on univariable analysis there was a decreased probability of detecting an adenoma with the increased number of endoscopies prior to the index colonoscopy. While the association between adenoma detection and photodocumentation of the cecum as well as prior polyp removal was inconclusive. While on multivariable analysis the association between the number of hours prior to the index colonoscopy was inconclusive, this is most probably due to the small number of individuals when the analysis was limited to average risk individuals. 
The retrospective nature of the study eliminated the possibility of a Hawthorne effect but also was a limiting factor, for instance some of the variables known to effect the adenoma formation like the metabolic syndrome ${ }^{124-126}$, smoking ${ }^{127-129}$, body mass index ${ }^{79}$, and socioeconomic status ${ }^{11}$ were not available

Some of the concerns raised with using ADR as a benchmark for colonoscopy quality is that it is a multifaceted variable, meaning that an adenoma has to be visualized, then be identified as an abnormality ${ }^{130}$, be excised or biopsied, and subsequently retrieved for pathological examination ${ }^{117}$. Thus ADR could be affected at each stage by a number of variables and be confounded by any factor that affects the sequence of adenoma removal.

Alternatively, if endoscopists are going to be benchmarked according to ADRs as is currently recommended, they most probably will be more meticulous in their exams, and would have a low threshold for repeating the exam in cases of suboptimal cleansing preparation as "unclean" colons may obscure adenomas that are flat or small.

Our study was inconclusive with regards to the detection of adenomas in those where the cecum was intubated, but other studies found that the cecal intubation rate was not associated with decreased interval CRC (incidence of CRC between the initial colonoscopy and the follow up colonoscopy). ${ }^{131}$ Perhaps because of more difficult detection of flatter polyps in the right colon (or poorer preps affecting the ascending colon), or even, a differential growth rate of adenomas in that colonic segment ${ }^{44,132}$. Also the results that we obtained might be of limited generalizability as the patient population referred to a tertiary care center might differ in many aspects from those seen on a community level. 


\subsection{Conclusion}

In conclusion, patient characteristics as well as, increased time from the start of the endoscopy session until the index colonoscopy was associated with decreased adenoma detection. This finding, which suggests operator fatigue, implies that there might be an optimal length of time for endoscopy sessions. This would be an important factor that should be taken into account in endoscopy scheduling. Further research is required to evaluate the effect of prolonged endoscopy sessions, as is commonly performed, on the detection of adenomas during screening colonoscopy. 


\section{CHAPTER VI: REFERENCES}

1. Jemal A, Siegel R, Xu J, Ward E. Cancer statistics, 2010. CA Cancer J Clin 2010;60:277-300.

2. Edwards BK, Ward E, Kohler BA, et al. Annual report to the nation on the status of cancer, 1975-2006, featuring colorectal cancer trends and impact of interventions (risk factors, screening, and treatment) to reduce future rates. Cancer 2010;116:544-73.

3. Fletcher RW. Clinical Epidemiology: The Essentials. Fourth ed. Philadelphia, Pennsylvania: Lipilkinspincott Wiliams \& W; 2005.

4. Rothman KJ, Greenland S. Causation and causal inference in epidemiology. Am J Public Health 2005;95 Suppl 1:S144-50.

5. Winawer SJ, Fletcher RH, Miller L, et al. Colorectal cancer screening: clinical guidelines and rationale. Gastroenterology 1997;112:594-642.

6. Pignone M, Rich M, Teutsch SM, Berg AO, Lohr KN. Screening for colorectal cancer in adults at average risk: a summary of the evidence for the U.S. Preventive Services Task Force. Ann Intern Med 2002;137:132-41.

7. Walsh JM, Terdiman JP. Colorectal cancer screening: scientific review. JAMA 2003;289:1288-96.

8. Kahi CJ, Imperiale TF, Juliar BE, Rex DK. Effect of screening colonoscopy on colorectal cancer incidence and mortality. Clin Gastroenterol Hepatol 2009;7:770-5; quiz 11.

9. Baxter NN, Goldwasser MA, Paszat LF, Saskin R, Urbach DR, Rabeneck

L. Association of colonoscopy and death from colorectal cancer. Ann Intern Med 2009; $150: 1-8$.

10. Rex DK, Johnson DA, Anderson JC, Schoenfeld PS, Burke CA, Inadomi JM. American College of Gastroenterology guidelines for colorectal cancer screening 2009 [corrected]. Am J Gastroenterol 2009;104:739-50.

11. Singh SM, Paszat LF, Li C, He J, Vinden C, Rabeneck L. Association of socioeconomic status and receipt of colorectal cancer investigations: a populationbased retrospective cohort study. CMAJ 2004;171:461-5.

12. Porta M. A Dictionary of Epidemiology. Fifth ed. New York: Oxford University Press; 2008.

13. Church JM. Complete colonoscopy: how often? And if not, why not? Am J Gastroenterol 1994;89:556-60.

14. Rathgaber SW, Wick TM. Colonoscopy completion and complication rates in a community gastroenterology practice. Gastrointest Endosc 2006;64:55662.

15. Harewood GC. Relationship of colonoscopy completion rates and endoscopist features. Dig Dis Sci 2005;50:47-51.

16. Rex DK. Quality in colonoscopy: cecal intubation first, then what? Am J Gastroenterol 2006;101:732-4.

17. Rex DK. Colonoscopy turning the focus on quality. Dig Liver Dis 2002;34:831-2.

18. Lieberman D. A call to action--measuring the quality of colonoscopy. N Engl J Med 2006;355:2588-9. 
19. Rex DK. Who is the best colonoscopist? Gastrointest Endosc 2007;65:145-50.

20. Rex DK, Petrini JL, Baron TH, et al. Quality indicators for colonoscopy. Am J Gastroenterol 2006;101:873-85.

21. Jemal A, Murray T, Ward E, et al. Cancer statistics, 2005. CA Cancer J Clin 2005;55:10-30.

22. Edwards BK, Brown ML, Wingo PA, et al. Annual report to the nation on the status of cancer, 1975-2002, featuring population-based trends in cancer treatment. J Natl Cancer Inst 2005;97:1407-27.

23. Lieberman DA, Weiss DG, Bond JH, Ahnen DJ, Garewal H, Chejfec G.

Use of colonoscopy to screen asymptomatic adults for colorectal cancer. Veterans Affairs Cooperative Study Group 380. N Engl J Med 2000;343:162-8.

24. Rothman KJ. Epidemiology an Introduction. New York: Oxford University Press; 2002.

25. Winawer SJ. Natural history of colorectal cancer. Am J Med 1999;106:3S$6 \mathrm{~S}$; discussion $50 \mathrm{~S}-1 \mathrm{~S}$.

26. Winawer SJ, Zauber AG, Ho MN, et al. Prevention of colorectal cancer by colonoscopic polypectomy. The National Polyp Study Workgroup. N Engl J Med 1993;329:1977-81.

27. Jorgensen OD, Kronborg O, Fenger C. The Funen Adenoma Follow-up

Study. Incidence and death from colorectal carcinoma in an adenoma surveillance program. Scand J Gastroenterol 1993;28:869-74.

28. Thiis-Evensen E, Hoff GS, Sauar J, Langmark F, Majak BM, Vatn MH. Population-based surveillance by colonoscopy: effect on the incidence of colorectal cancer. Telemark Polyp Study I. Scand J Gastroenterol 1999;34:41420.

29. Hoff G, Sauar J, Vatn MH, et al. Polypectomy of adenomas in the prevention of colorectal cancer: 10 years' follow-up of the Telemark Polyp Study I. A prospective, controlled population study. Scand J Gastroenterol 1996;31:1006-10.

30. Levin B, Lieberman DA, McFarland B, et al. Screening and surveillance for the early detection of colorectal cancer and adenomatous polyps, 2008: a joint guideline from the American Cancer Society, the US Multi-Society Task Force on Colorectal Cancer, and the American College of Radiology. Gastroenterology 2008; 134:1570-95.

31. Screening for colorectal cancer: U.S. Preventive Services Task Force recommendation statement. Ann Intern Med 2008;149:627-37.

32. Leddin D, Hunt R, Champion M, et al. Canadian Association of Gastroenterology and the Canadian Digestive Health Foundation: Guidelines on colon cancer screening. Can J Gastroenterol 2004;18:93-9.

33. Colorectal cancer screening. Recommendation statement from the Canadian task force on preventive health care. Can Fam Physician 2001;47:18113,5 .

34. Winawer S, Fletcher R, Rex D, et al. Colorectal cancer screening and surveillance: clinical guidelines and rationale-Update based on new evidence. Gastroenterology 2003;124:544-60. 
35. Smith RA, Cokkinides V, Brooks D, Saslow D, Brawley OW. Cancer screening in the United States, 2010: a review of current American Cancer Society guidelines and issues in cancer screening. CA Cancer J Clin 2010;60:99119.

36. Rex DK, Bond JH, Winawer S, et al. Quality in the technical performance of colonoscopy and the continuous quality improvement process for colonoscopy: recommendations of the U.S. Multi-Society Task Force on Colorectal Cancer. Am J Gastroenterol 2002;97:1296-308.

37. Meissner HI, Breen N, Klabunde CN, Vernon SW. Patterns of colorectal cancer screening uptake among men and women in the United States. Cancer Epidemiol Biomarkers Prev 2006;15:389-94.

38. Whitlock EP, Lin JS, Liles E, Beil TL, Fu R. Screening for colorectal cancer: a targeted, updated systematic review for the U.S. Preventive Services Task Force. Ann Intern Med 2008;149:638-58.

39. Cotton PB, Durkalski VL, Pineau BC, et al. Computed tomographic colonography (virtual colonoscopy): a multicenter comparison with standard colonoscopy for detection of colorectal neoplasia. JAMA 2004;291:1713-9. 40. Rockey DC, Paulson E, Niedzwiecki D, et al. Analysis of air contrast barium enema, computed tomographic colonography, and colonoscopy: prospective comparison. Lancet 2005;365:305-11.

41. Forde KA. Colonoscopic screening for colon cancer. Surg Endosc 2006;20 Suppl 2:S471-4.

42. Brady AP, Stevenson GW, Stevenson I. Colorectal cancer overlooked at barium enema examination and colonoscopy: a continuing perceptual problem. Radiology 1994;192:373-8.

43. Rex DK, Rahmani EY, Haseman JH, Lemmel GT, Kaster S, Buckley JS. Relative sensitivity of colonoscopy and barium enema for detection of colorectal cancer in clinical practice. Gastroenterology 1997;112:17-23.

44. Bressler B, Paszat LF, Vinden C, Li C, He J, Rabeneck L. Colonoscopic miss rates for right-sided colon cancer: a population-based analysis. Gastroenterology 2004;127:452-6.

45. Brenner H, Hoffmeister M, Arndt V, Stegmaier C, Altenhofen L, Haug U. Protection from right- and left-sided colorectal neoplasms after colonoscopy: population-based study. J Natl Cancer Inst 2010;102:89-95.

46. Rex DK, Cutler CS, Lemmel GT, et al. Colonoscopic miss rates of adenomas determined by back-to-back colonoscopies. Gastroenterology 1997;112:24-8.

47. Heresbach D, Barrioz T, Lapalus MG, et al. Miss rate for colorectal neoplastic polyps: a prospective multicenter study of back-to-back video colonoscopies. Endoscopy 2008;40:284-90.

48. Pickhardt PJ, Choi JR, Hwang I, et al. Computed tomographic virtual colonoscopy to screen for colorectal neoplasia in asymptomatic adults. N Engl J Med 2003;349:2191-200.

49. Simmons DT, Harewood GC, Baron TH, et al. Impact of endoscopist withdrawal speed on polyp yield: implications for optimal colonoscopy withdrawal time. Aliment Pharmacol Ther 2006;24:965-71. 
50. Barclay RL, Vicari JJ, Doughty AS, Johanson JF, Greenlaw RL. Colonoscopic withdrawal times and adenoma detection during screening colonoscopy. N Engl J Med 2006;355:2533-41.

51. Shaukat A, Oancea C, Bond JH, Church TR, Allen JI. Variation in detection of adenomas and polyps by colonoscopy and change over time with a performance improvement program. Clin Gastroenterol Hepatol 2009;7:1335-40.

52. Dellon ES, Lippmann QK, Sandler RS, Shaheen NJ. Gastrointestinal endoscopy nurse experience and polyp detection during screening colonoscopy. Clin Gastroenterol Hepatol 2008;6:1342-7.

53. Rex DK, Chadalawada V, Helper DJ. Wide angle colonoscopy with a prototype instrument: impact on miss rates and efficiency as determined by backto-back colonoscopies. Am J Gastroenterol 2003;98:2000-5.

54. Aminalai A, Rosch T, Aschenbeck J, et al. Live Image Processing Does Not Increase Adenoma Detection Rate During Colonoscopy: A Randomized Comparison Between FICE and Conventional Imaging (Berlin Colonoscopy Project 5, BECOP-5). Am J Gastroenterol.

55. Chung SJ, Kim D, Song JH, et al. Efficacy of computed virtual chromoendoscopy on colorectal cancer screening: a prospective, randomized, back-to-back trial of Fuji Intelligent Color Enhancement versus conventional colonoscopy to compare adenoma miss rates. Gastrointest Endosc 2010;72:13642.

56. Hurlstone DP, Cross SS, Slater R, Sanders DS, Brown S. Detecting diminutive colorectal lesions at colonoscopy: a randomised controlled trial of pancolonic versus targeted chromoscopy. Gut 2004;53:376-80.

57. Lapalus MG, Helbert T, Napoleon B, Rey JF, Houcke P, Ponchon T. Does chromoendoscopy with structure enhancement improve the colonoscopic adenoma detection rate? Endoscopy 2006;38:444-8.

58. Kahi CJ, Anderson JC, Waxman I, et al. High-definition chromocolonoscopy vs. high-definition white light colonoscopy for average-risk colorectal cancer screening. Am J Gastroenterol 2010;105:1301-7.

59. Su MY, Hsu CM, Ho YP, Chen PC, Lin CJ, Chiu CT. Comparative study of conventional colonoscopy, chromoendoscopy, and narrow-band imaging systems in differential diagnosis of neoplastic and nonneoplastic colonic polyps. Am J Gastroenterol 2006;101:2711-6.

60. Fu KI, Kaji Y, Fujimori T. Magnifying colonoscopy or "ultrahigh" magnifying colonoscopy: that is the question. Gastrointest Endosc 2006;64:1036; author reply -7 .

61. Dekker E, Fockens P. New imaging techniques at colonoscopy: tissue spectroscopy and narrow band imaging. Gastrointest Endosc Clin N Am 2005;15:703-14.

62. Horimatsu T, Sano Y, Kaneko K, et al. Relationship between MVD and meshed-capillaries using magnifying NBI colonoscopy in colorectal precursor lesions. Hepatogastroenterology 2009;56:372-7.

63. Barthel JS. Adenoma detection and retroscopy. Gastrointest Endosc 2010;71:557-9. 
64. Citarda F, Tomaselli G, Capocaccia R, Barcherini S, Crespi M. Efficacy in standard clinical practice of colonoscopic polypectomy in reducing colorectal cancer incidence. Gut 2001;48:812-5.

65. Dove-Edwin I, Sasieni P, Adams J, Thomas HJ. Prevention of colorectal cancer by colonoscopic surveillance in individuals with a family history of colorectal cancer: 16 year, prospective, follow-up study. BMJ 2005;331:1047. 66. Brenner H, Chang-Claude J, Seiler CM, Sturmer T, Hoffmeister M. Does a negative screening colonoscopy ever need to be repeated? Gut 2006;55:1145-50. 67. Martinez ME, Baron JA, Lieberman DA, et al. A pooled analysis of advanced colorectal neoplasia diagnoses after colonoscopic polypectomy. Gastroenterology 2009;136:832-41.

68. Robertson DJ, Greenberg ER, Beach M, et al. Colorectal cancer in patients under close colonoscopic surveillance. Gastroenterology 2005;129:34-41.

69. Stock C, Haug U, Brenner H. Population-based prevalence estimates of history of colonoscopy or sigmoidoscopy: review and analysis of recent trends. Gastrointest Endosc; 71:366-81 e2.

70. Rabeneck L, Paszat LF, Saskin R, Stukel TA. Association Between Colonoscopy Rates and Colorectal Cancer Mortality. Am J Gastroenterol. 71. Singh H, Nugent Z, Demers AA, Kliewer EV, Mahmud SM, Bernstein CN. The Reduction in Colorectal Cancer Mortality After Colonoscopy Varies by Site of the Cancer. Gastroenterology 2010.

72. Allison JE. Colorectal cancer screening guidelines: the importance of evidence and transparency. Gastroenterology 2010;138:1648-52 e2.

73. Lieberman DA, Faigel DO, Logan JR, et al. Assessment of the quality of colonoscopy reports: results from a multicenter consortium. Gastrointest Endosc 2009;69:645-53.

74. Kaminski MF, Regula J, Kraszewska E, et al. Quality indicators for colonoscopy and the risk of interval cancer. N Engl J Med 2010;362:1795-803.

75. Robertson DJ. Colonoscopy for colorectal cancer prevention: is it fulfilling the promise? Gastrointest Endosc 2010;71:118-20.

76. Pickhardt PJ, Nugent PA, Mysliwiec PA, Choi JR, Schindler WR. Location of adenomas missed by optical colonoscopy. Ann Intern Med 2004;141:352-9.

77. Lieberman D, Nadel M, Smith RA, et al. Standardized colonoscopy reporting and data system: report of the Quality Assurance Task Group of the National Colorectal Cancer Roundtable. Gastrointest Endosc 2007;65:757-66. 78. Hewett DG RD. Improving colonoscopy quality through health-care payment reform. Am J Gastroenterol 2010;105:1925-33.

79. Hassan C, Pickhardt PJ, Marmo R, Choi JR. Impact of lifestyle factors on colorectal polyp detection in the screening setting. Dis Colon Rectum 2010;53:1328-33.

80. Atkin W, Rogers P, Cardwell C, et al. Wide variation in adenoma detection rates at screening flexible sigmoidoscopy. Gastroenterology 2004; 126:1247-56. 
81. Lynch KL, Ahnen DJ, Byers T, Weiss DG, Lieberman DA. First-degree relatives of patients with advanced colorectal adenomas have an increased prevalence of colorectal cancer. Clin Gastroenterol Hepatol 2003;1:96-102. 82. Nam SY, Kim BC, Han KS, et al. Abdominal visceral adipose tissue predicts risk of colorectal adenoma in both sexes. Clin Gastroenterol Hepatol 2010;8:443-50 e1-2.

83. Kirkegaard H, Johnsen NF, Christensen J, Frederiksen K, Overvad K, Tjonneland A. Association of adherence to lifestyle recommendations and risk of colorectal cancer: a prospective Danish cohort study. BMJ 2010;341:c5504.

84. Leufkens AM, Duijnhoven FR, Siersema PD, et al. Cigarette Smoking and Colorectal Cancer Risk in the European Prospective Investigation into Cancer and Nutrition Study. Clin Gastroenterol Hepatol 2010.

85. Poynter JN, Haile RW, Siegmund KD, et al. Associations between smoking, alcohol consumption, and colorectal cancer, overall and by tumor microsatellite instability status. Cancer Epidemiol Biomarkers Prev 2009; 18:2745-50.

86. Radaelli F, Meucci G, Sgroi G, Minoli G. Technical performance of colonoscopy: the key role of sedation/analgesia and other quality indicators. Am J Gastroenterol 2008;103:1122-30.

87. Thomas-Gibson S, Rogers P, Cooper S, et al. Judgement of the quality of bowel preparation at screening flexible sigmoidoscopy is associated with variability in adenoma detection rates. Endoscopy 2006;38:456-60.

88. Harewood GC, Sharma VK, de Garmo P. Impact of colonoscopy preparation quality on detection of suspected colonic neoplasia. Gastrointest Endosc 2003;58:76-9.

89. Froehlich F, Wietlisbach V, Gonvers JJ, Burnand B, Vader JP. Impact of colonic cleansing on quality and diagnostic yield of colonoscopy: the European Panel of Appropriateness of Gastrointestinal Endoscopy European multicenter study. Gastrointest Endosc 2005;61:378-84.

90. Lai EJ, Calderwood AH, Doros G, Fix OK, Jacobson BC. The Boston bowel preparation scale: a valid and reliable instrument for colonoscopy-oriented research. Gastrointest Endosc 2009;69:620-5.

91. Imperiale TF, Wagner DR, Lin CY, Larkin GN, Rogge JD, Ransohoff DF. Risk of advanced proximal neoplasms in asymptomatic adults according to the distal colorectal findings. N Engl J Med 2000;343:169-74.

92. Sanchez W, Harewood GC, Petersen BT. Evaluation of polyp detection in relation to procedure time of screening or surveillance colonoscopy. Am J Gastroenterol 2004;99:1941-5.

93. Collins PD, Watson AJ. Is the rate of adenoma detection in colonoscopy influenced by the duration of colonoscope withdrawal? Nat Clin Pract Gastroenterol Hepatol 2007;4:428-9.

94. Taber A, Romagnuolo J. Effect of simply recording colonoscopy withdrawal time on polyp and adenoma detection rates. Gastrointest Endosc 2010;71:782-6. 
95. Gellad ZF, Weiss DG, Ahnen DJ, Lieberman DA, Jackson GL, Provenzale D. Colonoscopy withdrawal time and risk of neoplasia at 5 years: results from VA Cooperative Studies Program 380. Am J Gastroenterol 2010;105:1746-52.

96. van Rijn JC, Reitsma JB, Stoker J, Bossuyt PM, van Deventer SJ, Dekker

E. Polyp miss rate determined by tandem colonoscopy: a systematic review. Am J Gastroenterol 2006;101:343-50.

97. Waye JD, Heigh RI, Fleischer DE, et al. A retrograde-viewing device improves detection of adenomas in the colon: a prospective efficacy evaluation (with videos). Gastrointest Endosc 2010;71:551-6.

98. Lau PC, Sung JJ. Flat adenoma in colon: two decades of debate. J Dig Dis 2010;11:201-7.

99. Millan MS, Gross P, Manilich E, Church JM. Adenoma detection rate: the real indicator of quality in colonoscopy. Dis Colon Rectum 2008;51:1217-20.

100. Chen SC, Rex DK. Endoscopist can be more powerful than age and male gender in predicting adenoma detection at colonoscopy. Am J Gastroenterol 2007;102:856-61.

101. Ko CW, Dominitz JA, Green P, Kreuter W, Baldwin LM. Specialty differences in polyp detection, removal, and biopsy during colonoscopy. Am J Med 2010;123:528-35.

102. Imperiale TF, Glowinski EA, Juliar BE, Azzouz F, Ransohoff DF. Variation in polyp detection rates at screening colonoscopy. Gastrointest Endosc 2009;69:1288-95.

103. Singh H, Penfold RB, DeCoster C, et al. Colonoscopy and its complications across a Canadian regional health authority. Gastrointest Endosc 2009;69:665-71.

104. Hetzel JT, Huang CS, Coukos JA, et al. Variation in the detection of serrated polyps in an average risk colorectal cancer screening cohort. Am J Gastroenterol 2010;105:2656-64.

105. Rabeneck L, Paszat LF, Saskin R. Endoscopist specialty is associated with incident colorectal cancer after a negative colonoscopy. Clin Gastroenterol Hepatol;8:275-9.

106. Rabeneck L, Paszat LF, Saskin R. Endoscopist specialty is associated with incident colorectal cancer after a negative colonoscopy. Clin Gastroenterol Hepatol 2010;8:275-9.

107. Lin OS, Kozarek RA, Arai A, et al. The effect of periodic monitoring and feedback on screening colonoscopy withdrawal times, polyp detection rates, and patient satisfaction scores. Gastrointest Endosc 2010;71:1253-9.

108. Sanaka MR, Shah N, Mullen KD, Ferguson DR, Thomas C, McCullough AJ. Afternoon colonoscopies have higher failure rates than morning colonoscopies. Am J Gastroenterol 2006;101:2726-30.

109. Wells CD, Heigh RI, Sharma VK, et al. Comparison of morning versus afternoon cecal intubation rates. BMC Gastroenterol 2007;7:19.

110. Sanaka MR, Deepinder F, Thota PN, Lopez R, Burke CA. Adenomas are detected more often in morning than in afternoon colonoscopy. Am J

Gastroenterol 2009;104:1659-64; quiz 65. 
111. Chan MY, Cohen H, Spiegel BM. Fewer polyps detected by colonoscopy as the day progresses at a Veteran's Administration teaching hospital. Clin Gastroenterol Hepatol 2009;7:1217-23; quiz 143.

112. Munson GW, Harewood GC, Francis DL. Time of day variation in polyp detection rate for colonoscopies performed on a 3-hour shift schedule. Gastrointest Endosc 2010.

113. Rostom A, Jolicoeur E. Validation of a new scale for the assessment of bowel preparation quality. Gastrointest Endosc 2004;59:482-6.

114. R Development Core Team. R: A language and environment for statistical computing, version 2.12.0. R Foundation for Statistical Computing, Vienna, Austria. ISBN 3-900051-07-0, URL http://www.R-project.org. 2010.

115. Harewood GC, Chrysostomou K, Himy N, Leong WL. Impact of operator fatigue on endoscopy performance: implications for procedure scheduling. Dig Dis Sci 2009;54:1656-61.

116. Wang A, Hoda KM, Holub JL, Eisen GM. Does level of sedation impact detection of advanced neoplasia? Dig Dis Sci 2010;55:2337-43.

117. Church J. Adenoma detection rate and the quality of colonoscopy: the sword has two edges. Dis Colon Rectum 2008;51:520-3.

118. Peters SL, Hasan AG, Jacobson NB, Austin GL. Level of fellowship training increases adenoma detection rates. Clin Gastroenterol Hepatol 2010;8:439-42.

119. Rex DK, Hewett DG, Snover DC. Editorial: detection targets for colonoscopy: from variable detection to validation. Am J Gastroenterol 2010;105:2665-9.

120. Taber A RJ. Effect of simply recording colonoscopy withdrawal time on polyp and adenoma detection rates. Gastrointest Endosc 2010;71:782-6.

121. Inadomi JM. In search of quality colonoscopy. Gastroenterology 2008;135:1845-7.

122. Gupta S, Rockey DC. Colonoscopic withdrawal times and adenoma detection. N Engl J Med 2007;356:1174; author reply

123. Shen B. Colonoscopic withdrawal times and adenoma detection. N Engl J Med 2007;356:1174; author reply

124. Sato Y, Nozaki R, Yamada K, Takano M, Haruma K. Relation between obesity and adenomatous polyps of the large bowel. Dig Endosc 2009;21:154-7. 125. Siddiqui A, Pena Sahdala HN, Nazario HE, et al. Obesity is associated with an increased prevalence of advanced adenomatous colon polyps in a male veteran population. Dig Dis Sci 2009;54:1560-4.

126. Kaaks R, Toniolo P, Akhmedkhanov A, et al. Serum C-peptide, insulinlike growth factor (IGF)-I, IGF-binding proteins, and colorectal cancer risk in women. J Natl Cancer Inst 2000;92:1592-600.

127. Botteri E, Iodice S, Raimondi S, Maisonneuve P, Lowenfels AB. Cigarette smoking and adenomatous polyps: a meta-analysis. Gastroenterology 2008;134:388-95.

128. Giovannucci E, Colditz GA, Stampfer MJ, et al. A prospective study of cigarette smoking and risk of colorectal adenoma and colorectal cancer in U.S. women. J Natl Cancer Inst 1994;86:192-9. 
129. Giovannucci E, Rimm EB, Stampfer MJ, et al. A prospective study of cigarette smoking and risk of colorectal adenoma and colorectal cancer in U.S. men. J Natl Cancer Inst 1994;86:183-91.

130. Church JM, Muto T, Appau K. Flat lesions of the colorectal mucosa: differences in recognition between Japanese and American endoscopists. Dis Colon Rectum 2004;47:1462-6.

131. Kaminski M, Regula J, Kraszewska E, Polkowski M, Wojciechowska U, Didkowska J, Zwierko M, Rupinski M, Nowacki MP, Butruk E. Quality indicators for colonoscopy and the risk of interval cancer. N Engl J Med 2010:1795-803.

132. Singh H, Demers AA, Xue L, Turner D, Bernstein CN. Time trends in colon cancer incidence and distribution and lower gastrointestinal endoscopy utilization in Manitoba. Am J Gastroenterol 2008;103:1249-56. 


\section{CHAPTER VII: APENDICIES}

Box plot of age of patients based on adenoma detection

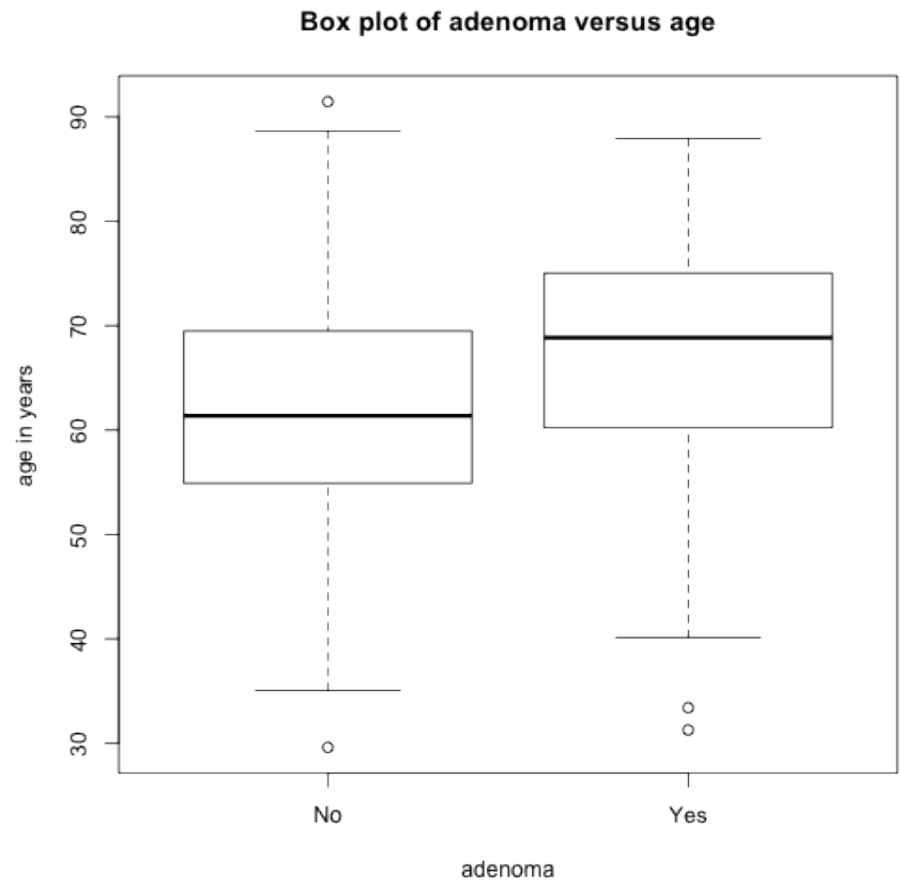

Box plot of age of patients based on the specialty of the endoscopist

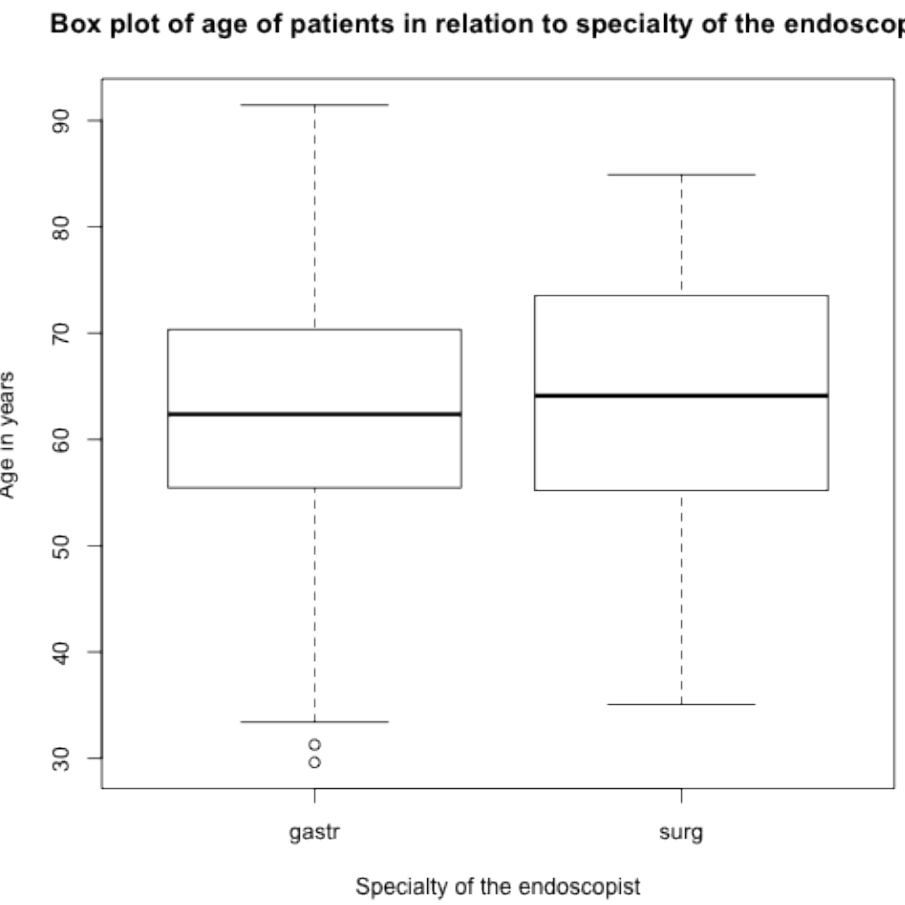


Box plot of age of patients based on the exposure to a prior colonoscopy

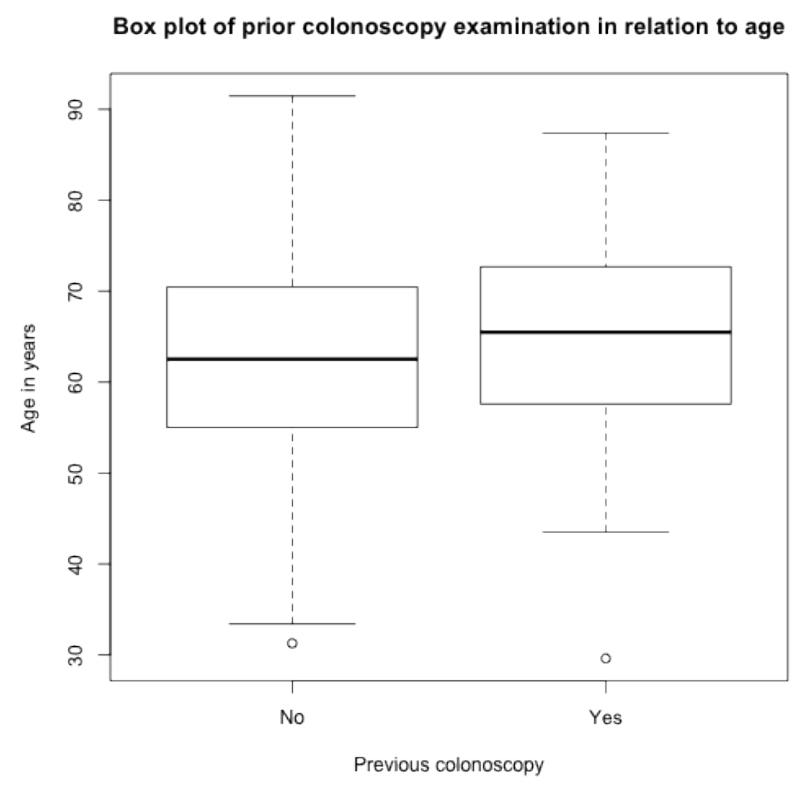

Box plot of age of patients based on the risk for the development of colorectal cancer.

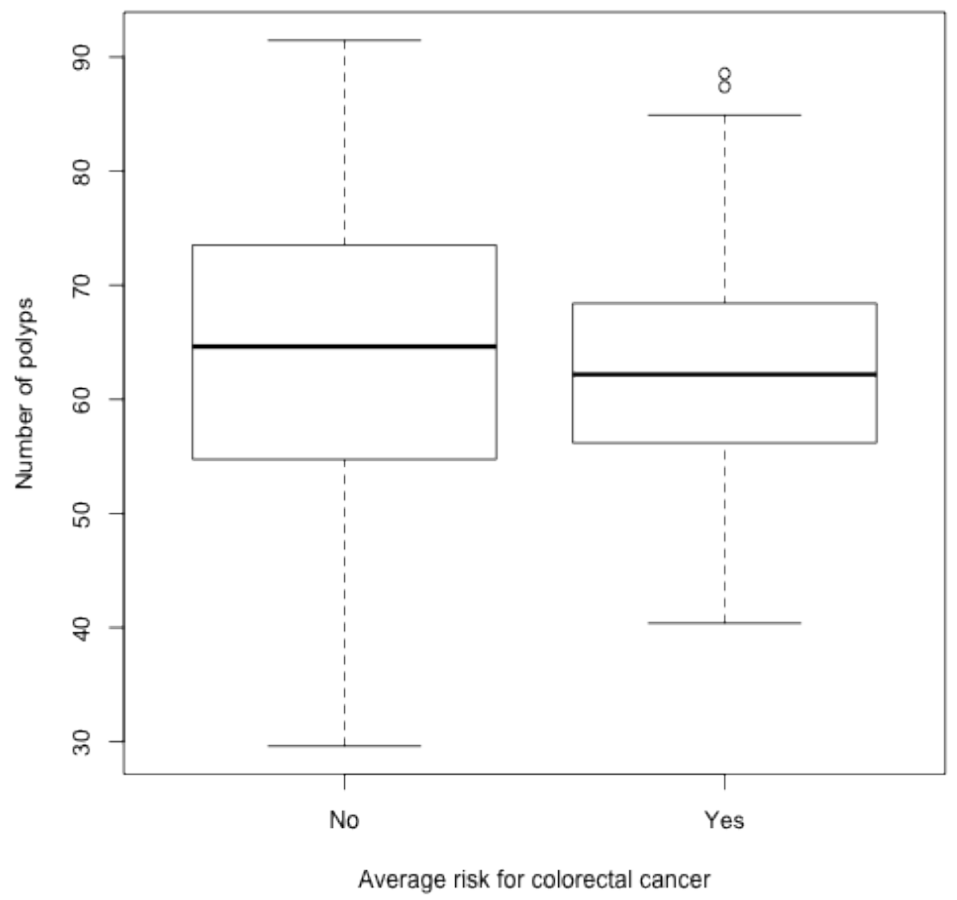


Box plot of age of patients based on the quality of the bowel preparation.

Plot of bowel preparation quality in relation to patients age

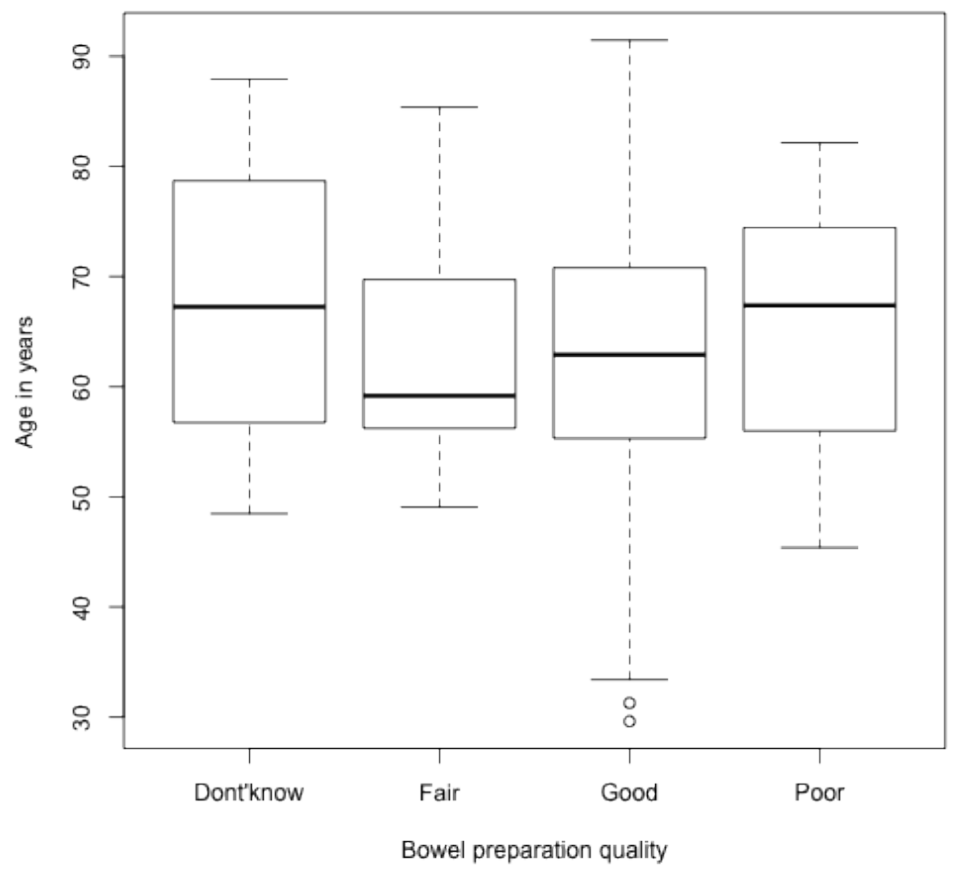

Scatter plot of age and the number of polyps detected.

Plot of number of polyps found in relation to patients age

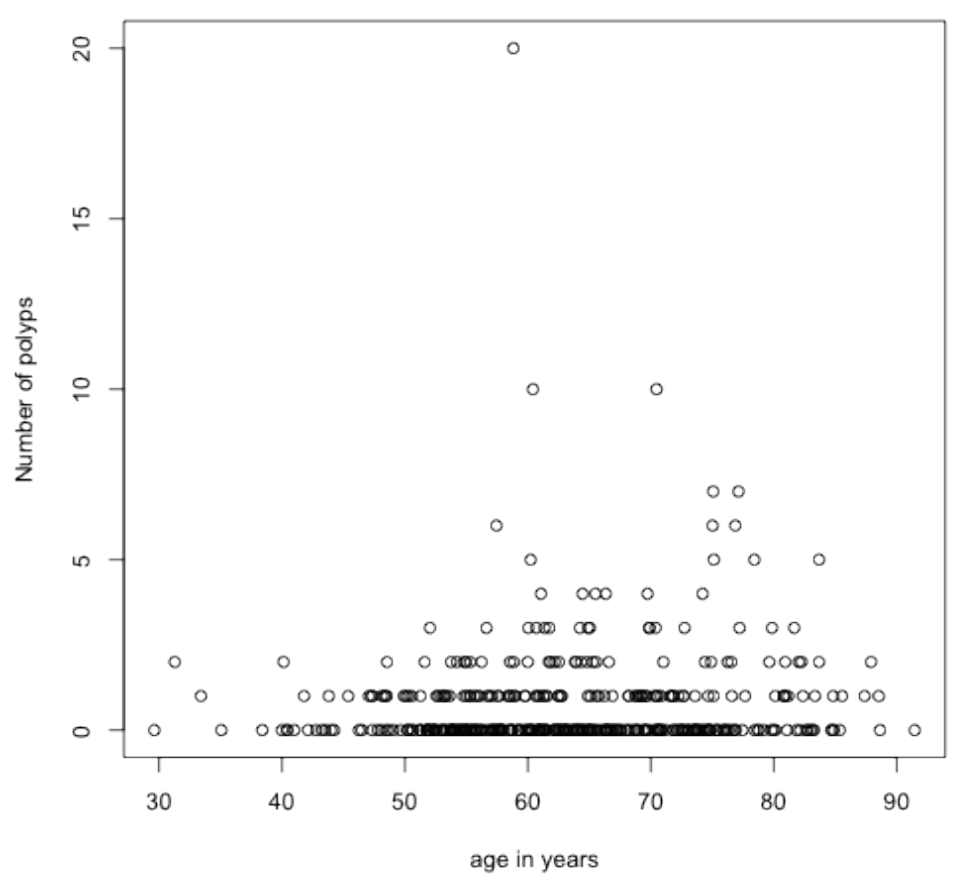


Scatter plot of age and the timing till the beginning of the index colonoscopy.

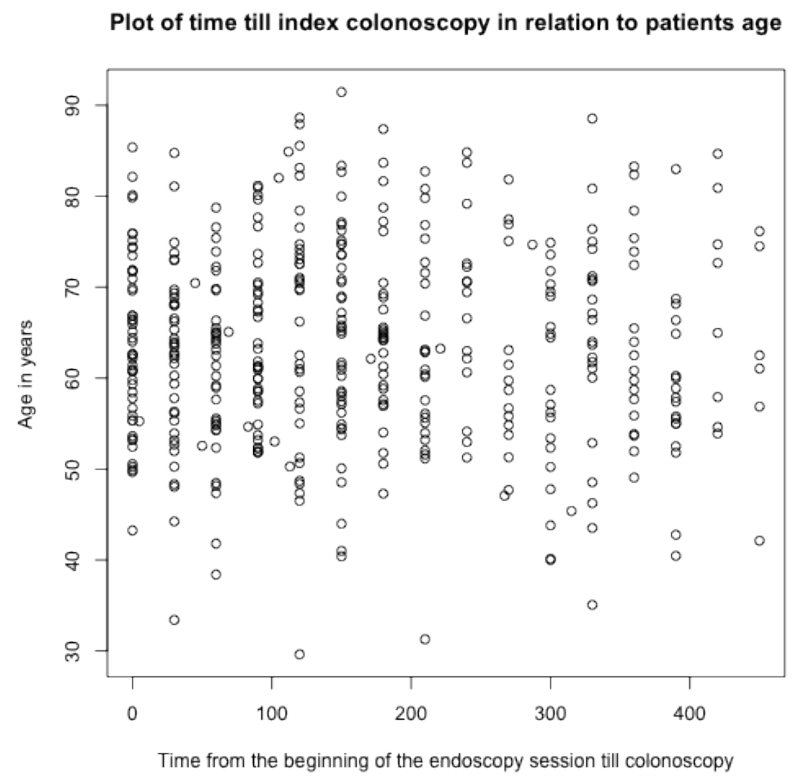

Scatter plot of age and the number of endoscopies till the index colonoscopy.

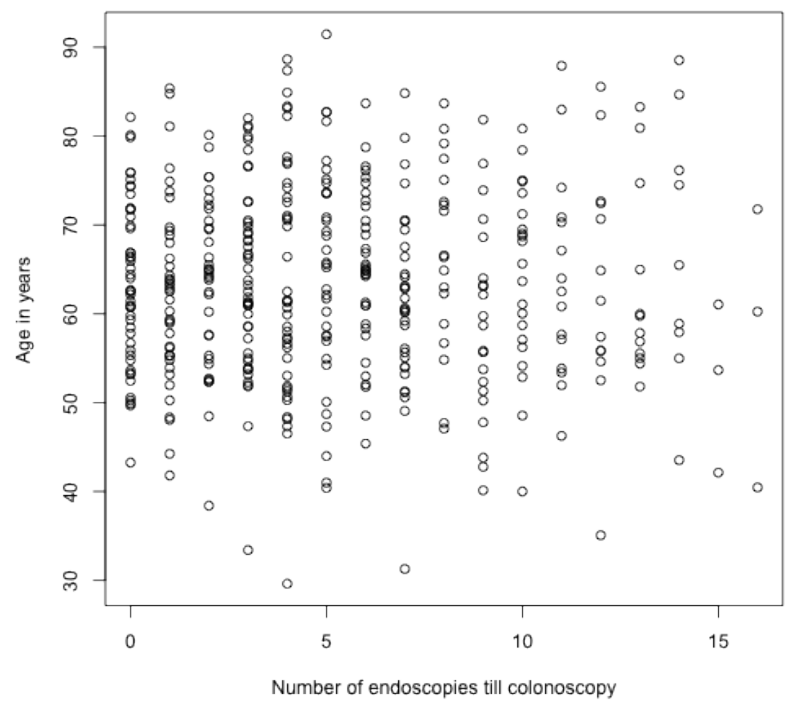


Box plot of adenomas and the number of polyps removed.

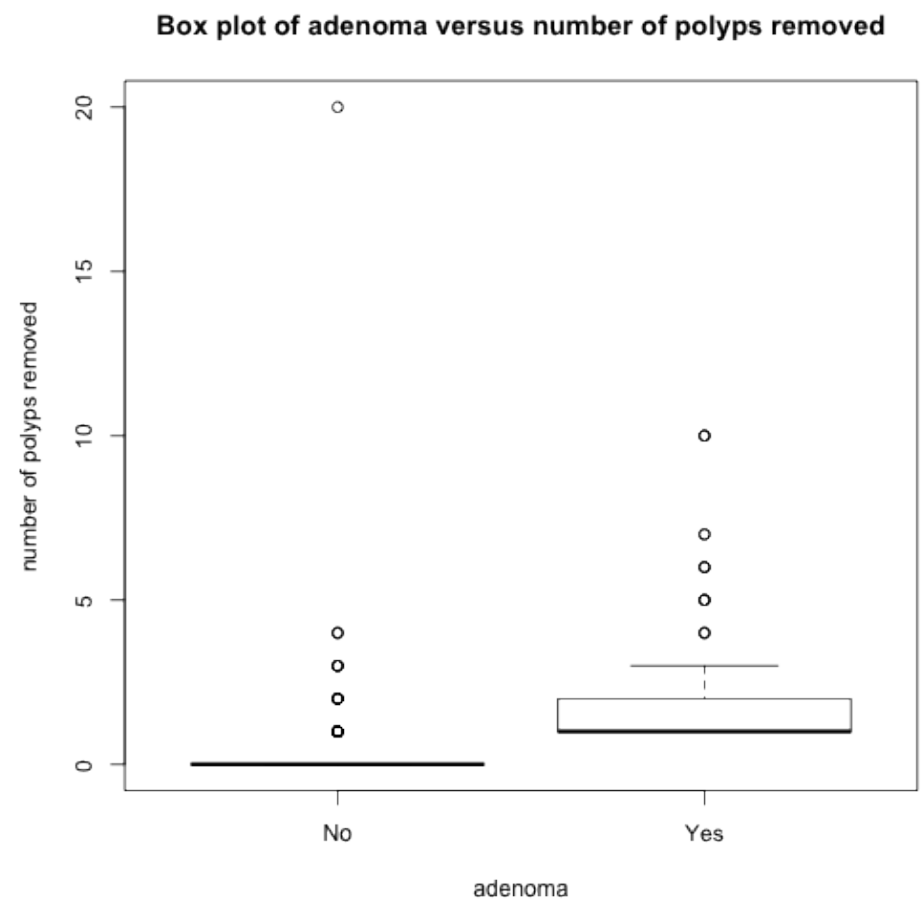

Scatter plot of the number of polyps detected and time till the start of the index colonoscopy.

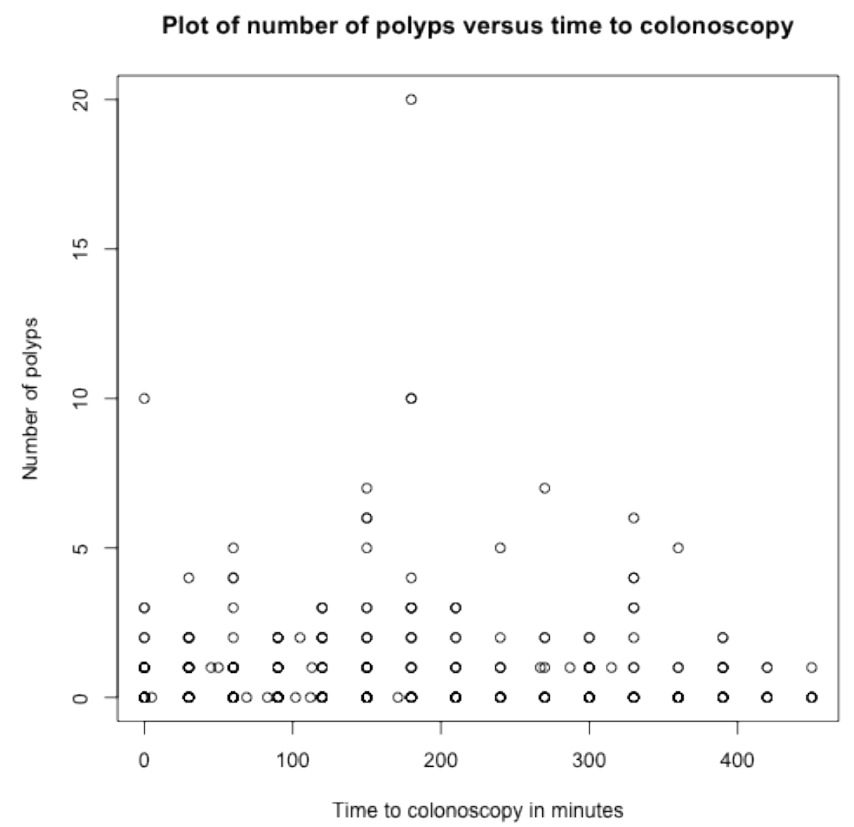


Box plot of adenomas and the time till index colonoscopy from the beginning of the endoscopy session.

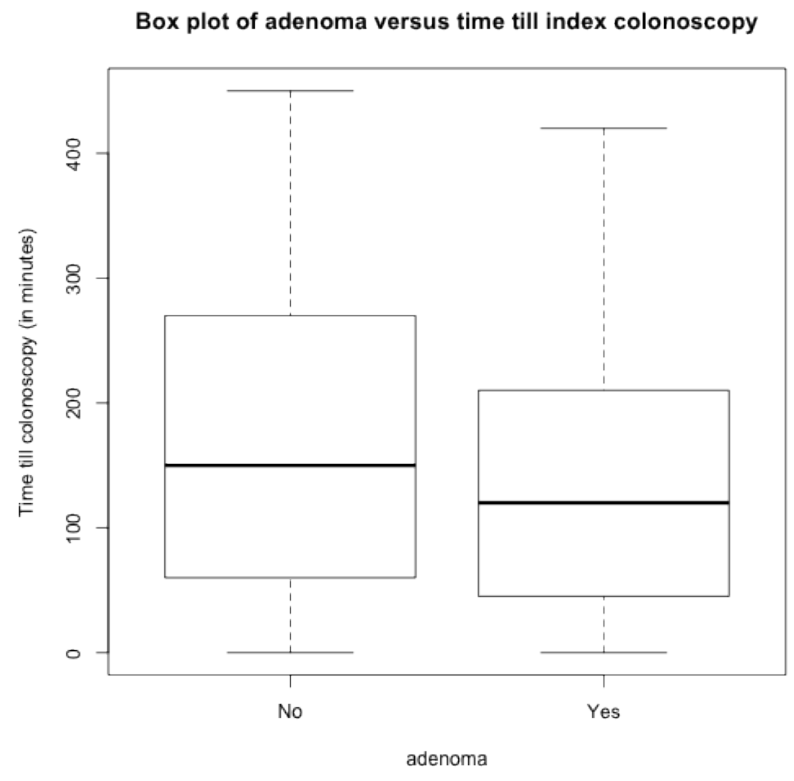

Box plot of adenomas and the number of endoscopies till index colonoscopy from the beginning of the endoscopy session.

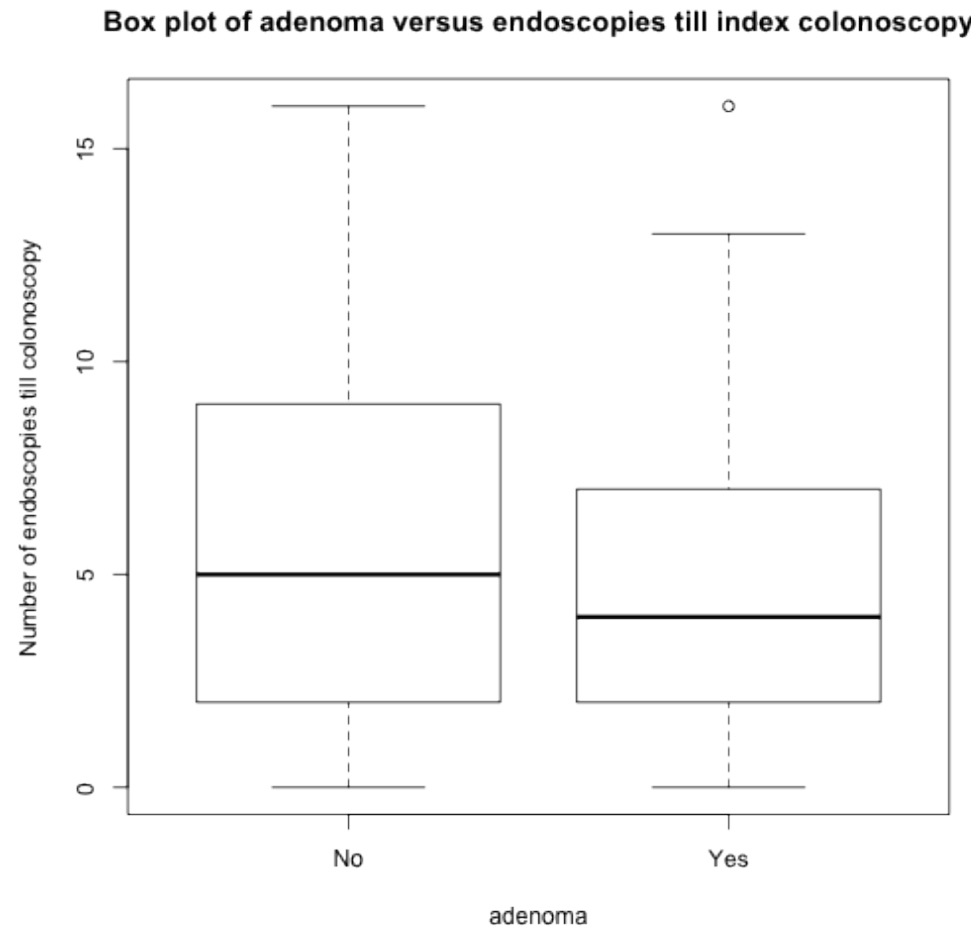


Box plot of adenomas and the number of colonoscopies till index colonoscopy from the beginning of the endoscopy session.

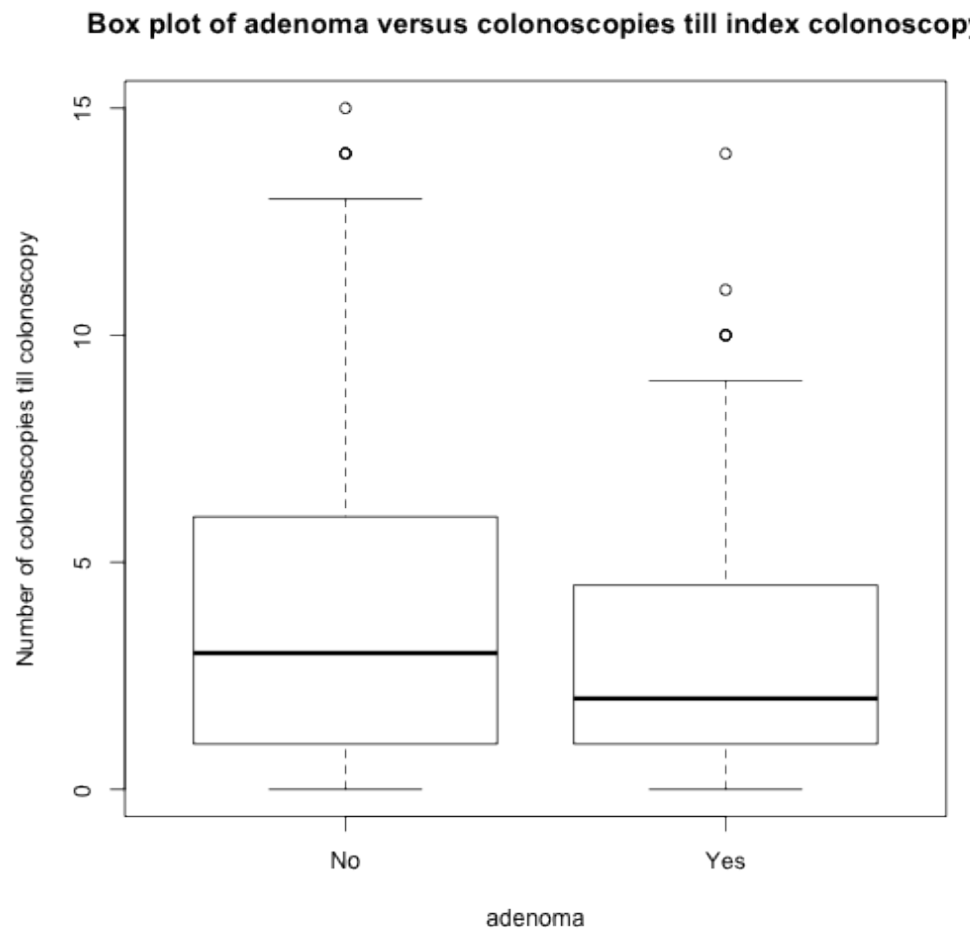

Box plot of adenomas in relation to the timing of endoscopy (am vs. pm)

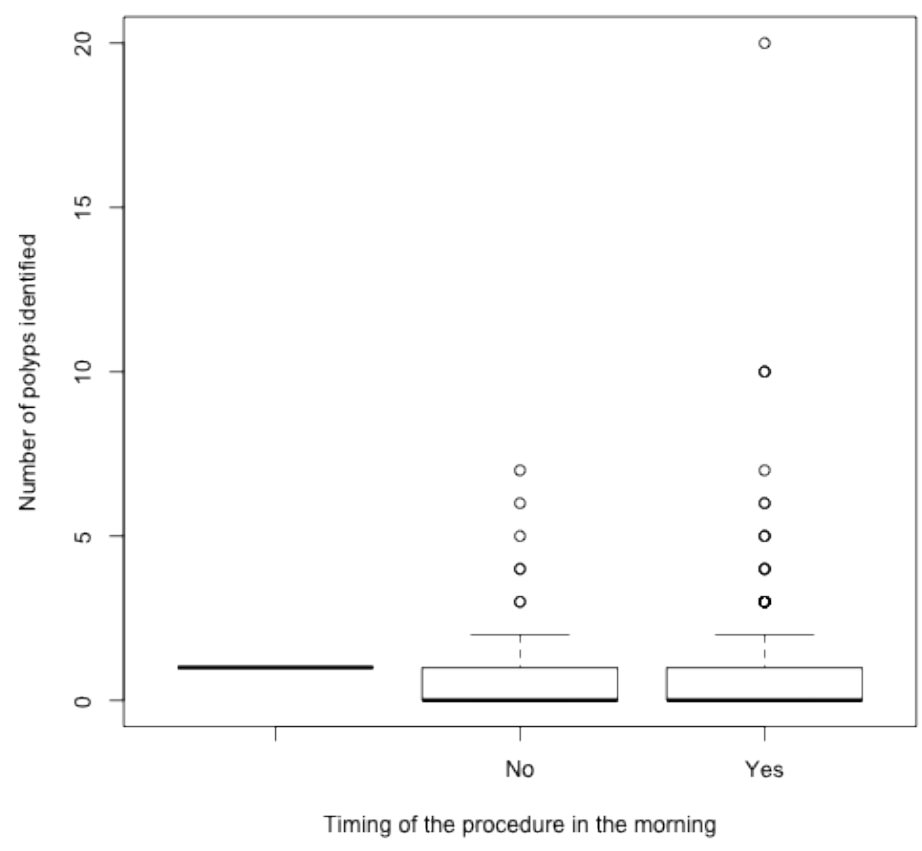


Box plot of the number of polyps detected in relation to cecal intubation.

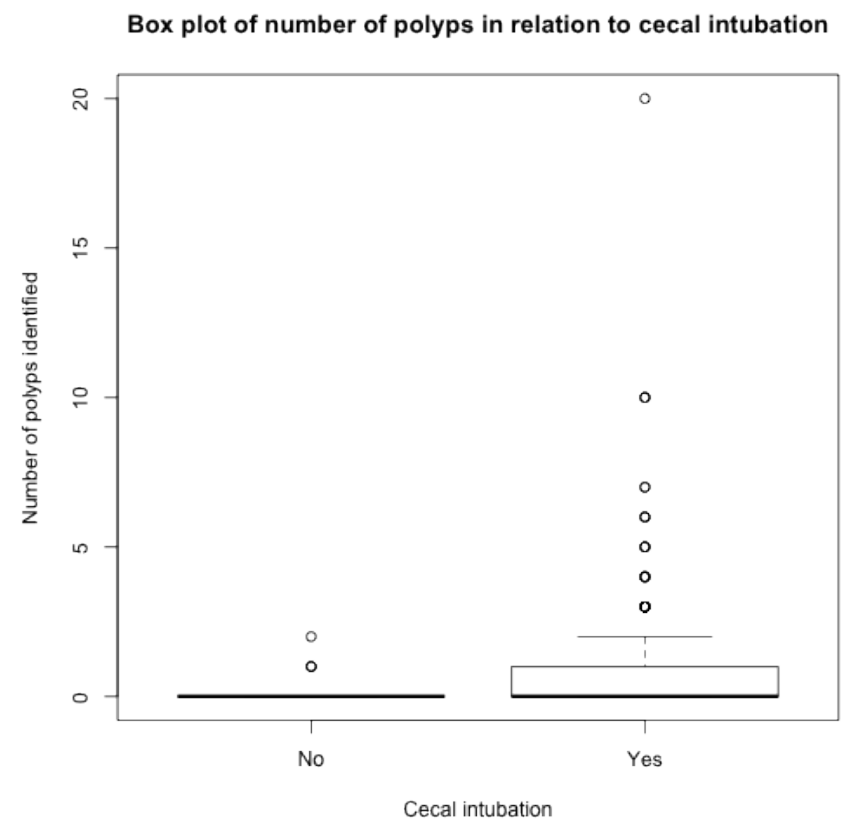

Box plot of the number of polyps detected in relation to the specialty of the endoscopist.

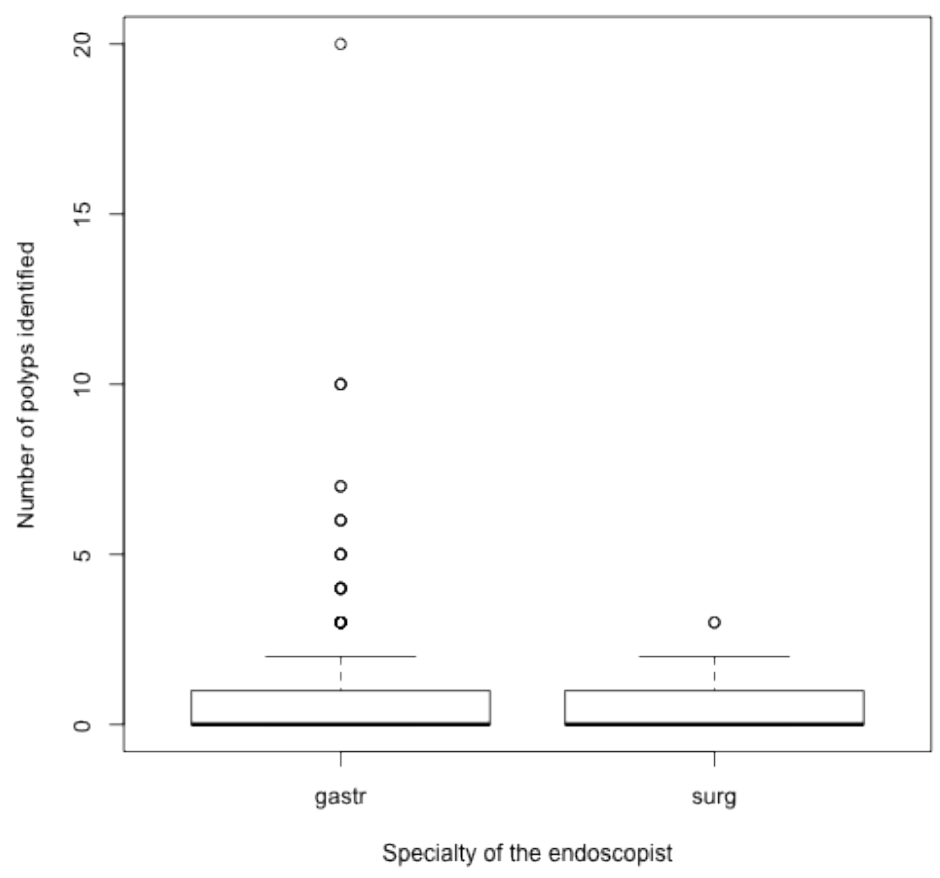


Box plot of the number of polyps detected in relation to the gender of the endoscopist.

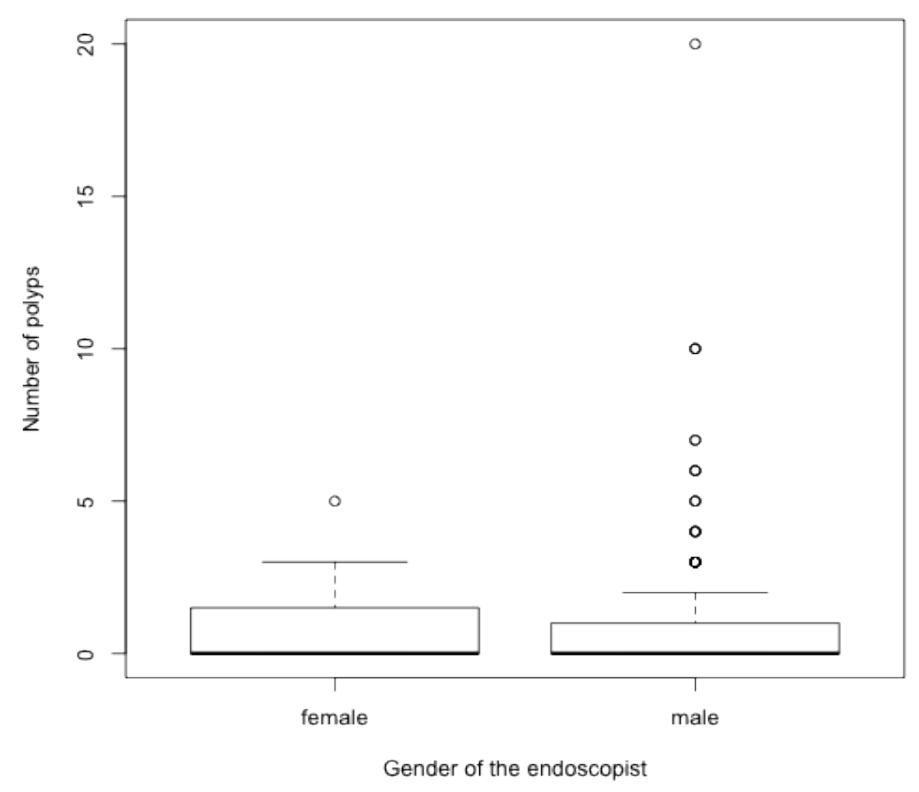

Box plot of the number of polyps detected in relation to the patient having a prior colonoscopy.

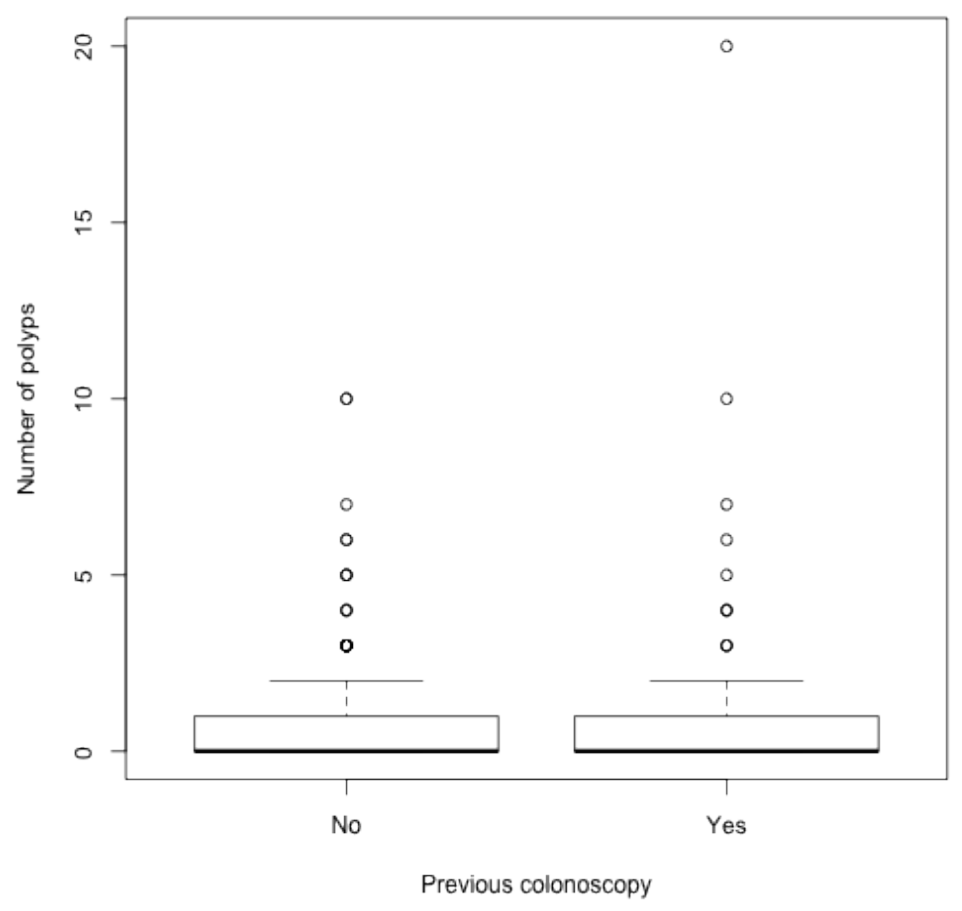


Box plot of the number of polyps detected in relation to the patient having a family history of colorectal cancer.

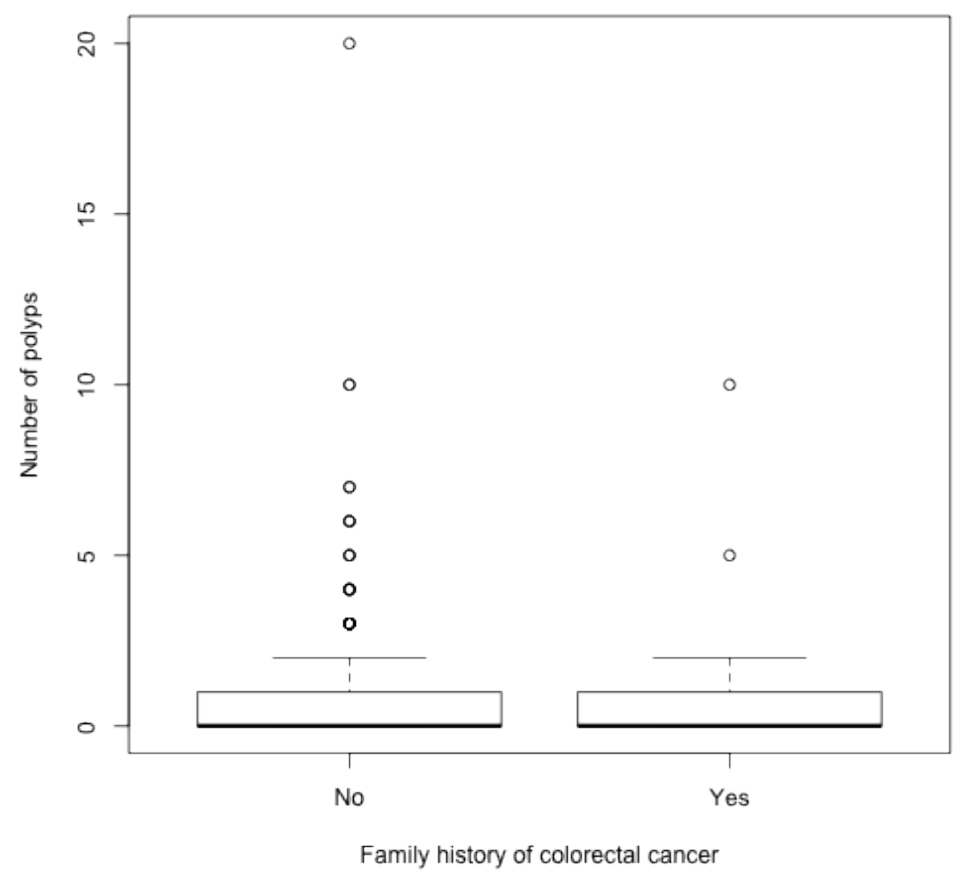

Box plot of the number of polyps detected in relation to the patient having a prior polyp removed

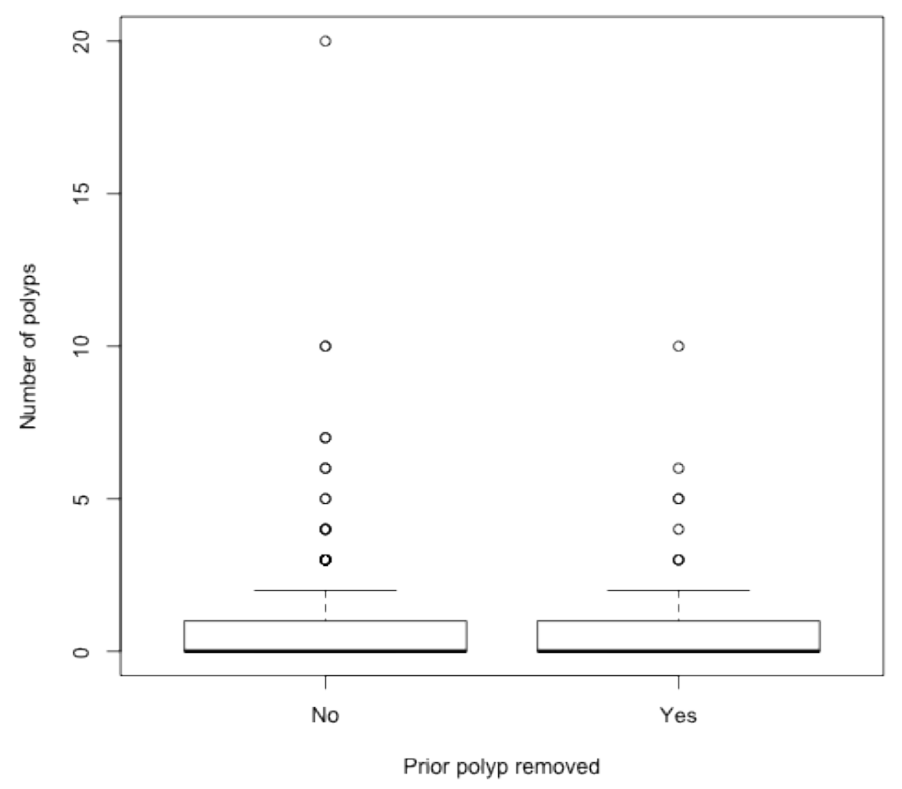


Box plot of the quality of the bowel preparation in relation to the number of colonoscopies from the beginning of the endoscopy session till the start of the index colonoscopy.

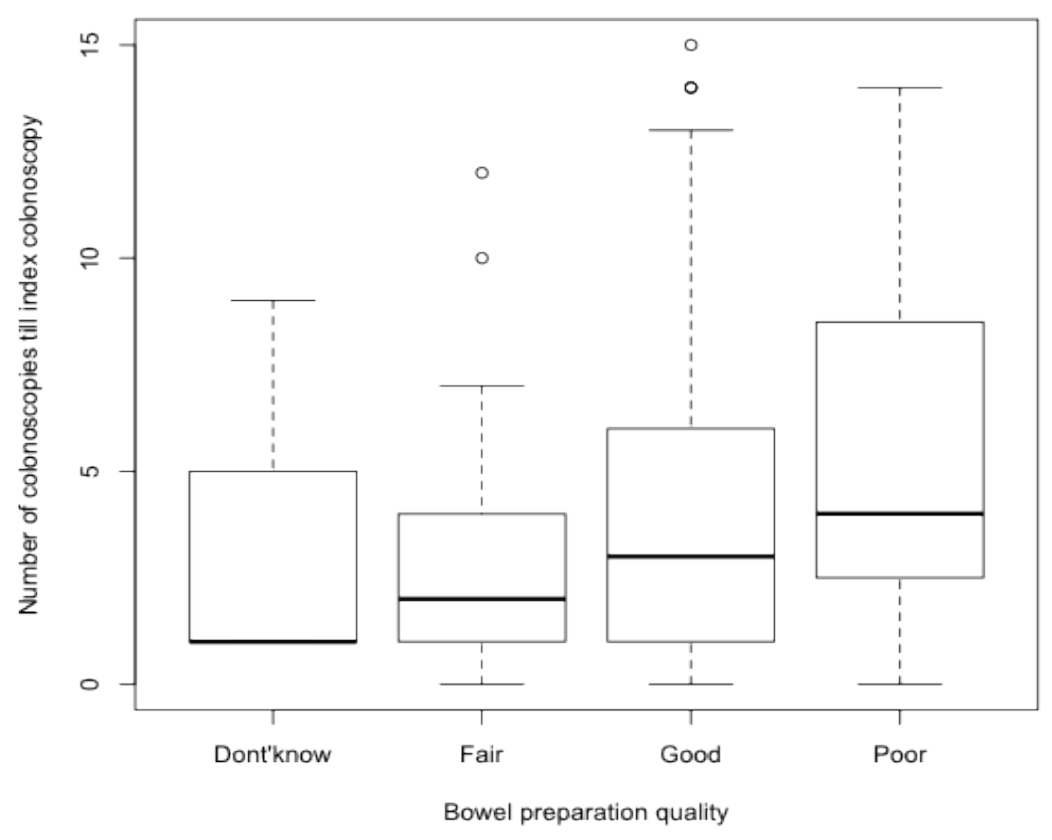

